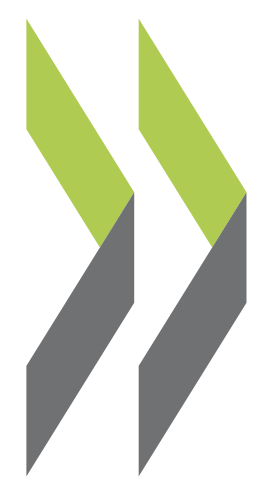

OECD Economics Department Working Papers No. 740

Improving the Policy Framework in Japan to Address Climate Change

Randall S. Jones, Byungseo Yoo 
Organisation de Coopération et de Développement Économiques

Organisation for Economic Co-operation and Development

04-Dec-2009

ECONOMICS DEPARTMENT

English - Or. English

IMPROVING THE POLICY FRAMEWORK IN JAPAN TO ADDRESS CLIMATE CHANGE

ECONOMICS DEPARTMENT WORKING PAPER No. 740

by Randall S. Jones and Byungseo Yoo

All Economics Department Working Papers are available through OECD's internet web site at www.oecd.org/eco/workingpapers

JT03275815

Document complet disponible sur OLIS dans son format d'origine

Complete document available on OLIS in its original format 


\section{ABSTRACT/ RÉSUMÉ}

\section{Improving the policy framework in Japan to address climate change}

Japan, a relatively energy-efficient country, has been active in combating climate change. Under the Kyoto Protocol, Japan is committed to reducing greenhouse gas emissions by $6 \%$ relative to 1990 over the period 2008-12. As of 2007, however, its emissions were up by $9 \%$. Japan has relied primarily on voluntary measures, which are monitored by the government, without binding commitments or price signals on carbon. It is essential to improve the policy framework to achieve its ambitious longer-term target of a $60 \%$ to $80 \%$ emission reduction by 2050 in a cost-effective manner. Japan should shift from voluntary measures to market-based instruments, notably a mandatory and comprehensive emission trading scheme, supplemented if necessary, by carbon taxes in areas not covered by trading, which minimise abatement costs and promote innovation to reduce emissions. Trading schemes should be linked to those in other countries, while expanding Japan's use of a wellfunctioning Clean Development Mechanism. Continued public support for R\&D in emission reduction technology, particularly in basic research, is important.

This Working Paper relates to the 2009 OECD Economic Survey of Japan (www.oecd.org/eco/surveys/Japan).

JEL classification: Q28, Q54, Q56, Q58

Keywords: climate change; greenhouse gas emissions; Kyoto protocol; emissions trading systems; Top Runner Programme; renewable energy; carbon sinks; Clean Development Mechanism; COP 15; carbon tax; Cool Earth 50; energy efficiency.

$$
* * * * * * *
$$

\section{Améliorer le cadre d'action au Japon pour lutter contre le changement climatique}

Le Japon, pays où l'efficacité énergétique est relativement élevée, lutte activement contre le changement climatique. En vertu du Protocole de Kyoto, il s'est engagé à réduire les émissions de gaz à effet de serre de $6 \%$ par rapport à 1990 sur la période 2008-12. En 2007, toutefois, ses émissions avaient augmenté de $9 \%$. Le Japon s'appuie essentiellement sur des mesures volontaires, qui sont contrôlées par le gouvernement, sans engagements contraignants ni signal-prix sur le carbone. Il doit absolument améliorer son cadre d'action pour pouvoir réaliser son objectif ambitieux à long terme d'une réduction des émissions de 60 à $80 \%$ d'ici à 2050 de manière efficace par rapport au coût. Le Japon devrait passer de mesures volontaires à des instruments de marché, notamment un système d'échange de droits d'émissions obligatoire et complet, complété si nécessaire par des taxes carbone dans les secteurs non couverts, de façon à minimiser les coûts de dépollution et à encourager l'innovation dans la réduction des émissions. Le système d'échange devrait être relié à ceux d'autres pays, alors que le recours par le Japon à un Mécanisme pour un développement propre fonctionnant correctement devrait se développer. L'aide publique continue à la R-D en matière de technologies de réduction des émissions, particulièrement dans la recherche fondamentale, est importante.

Ce Document de travail se rapporte à l'Étude économique de l'OCDE du Japon, 2009 (www.oecd.org/eco/etudes/japon).

Classification JEL : Q28, Q54, Q56, Q58

Mots clés: changement climatique ; émissions de gaz à effet de serre ; Protocole de Kyoto ; système d'échange de droits d'émissions ; programme Top Runner ; énergies renouvelables ; puits de carbone ; Mécanisme pour un développement propre ; COP 15 ; taxes carbone ; Cool Earth 50 ; efficacité énergétique.

Copyright OECD 2009

Application for permission to reproduce or translate all, or part of, this material should be made to: Head of Publications Service, OECD, 2 rue André-Pascal, 75775 Paris Cedex 16, France. 


\section{TABLE OF CONTENTS}

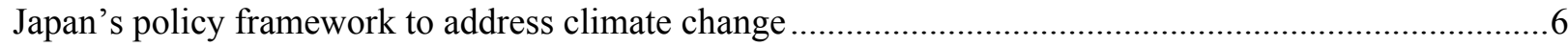

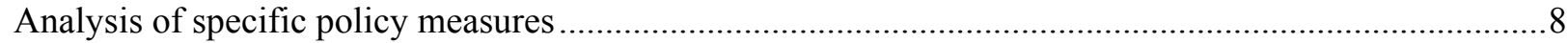

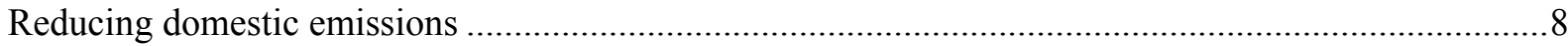

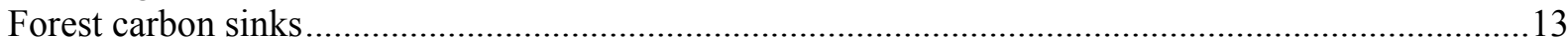

The Clean Development Mechanism and other Kyoto mechanisms......................................................14

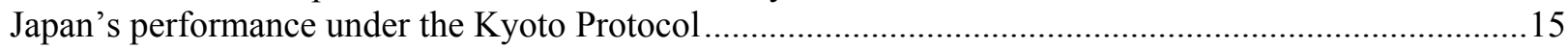

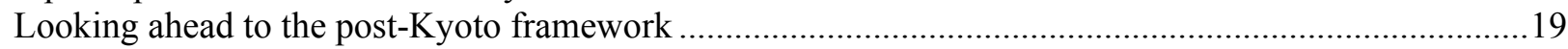

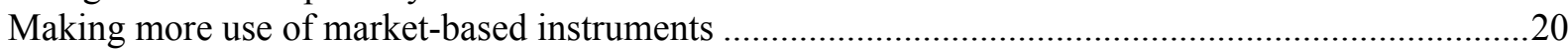

Reducing abatement costs by expanding the CDM and linking the ETS with other countries..............22

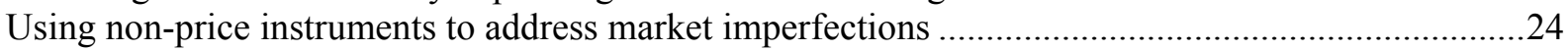

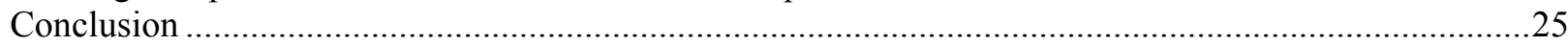

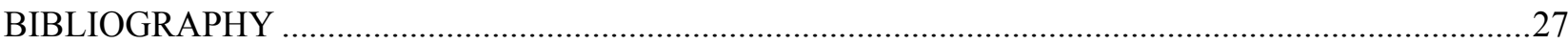

\section{Tables}

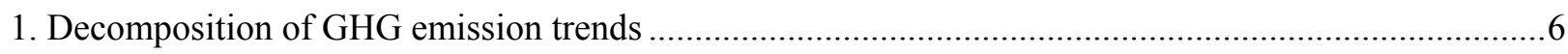

2. Overseas Development Assistance and the Clean Development Mechanism ....................................16

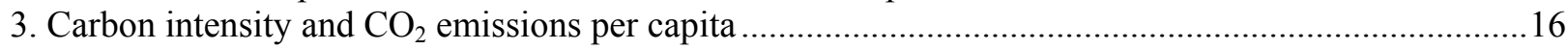

4. Changes in air pollutants and GHG emissions between 1990 and 2006.......................................19

5. Top ten nations in inventing climate-related technologies, 1998-2003 ...........................................25

\section{Figures}

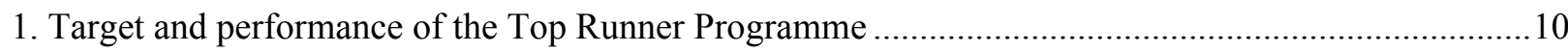

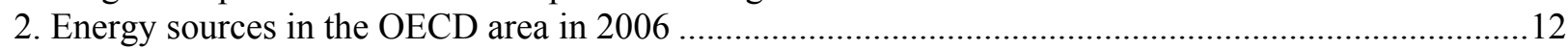

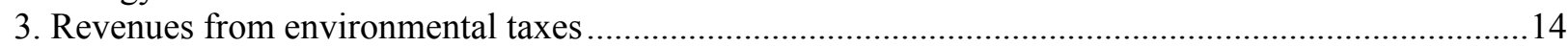

4. Overview of the Kyoto and mid-term emission targets in Japan ......................................................17

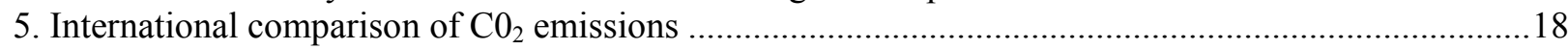

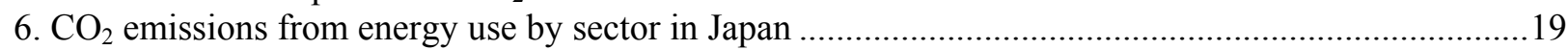

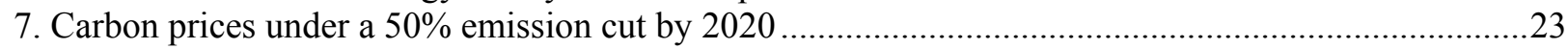


ECO/WKP(2009)81

\section{Boxes}

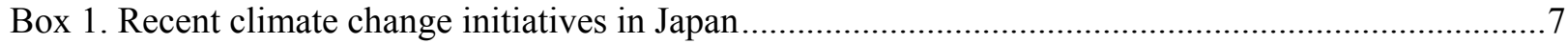

Box 2. Summary of recommendations to improve policies on climate change ......................................25 
ECO/WKP(2009)81

\title{
IMPROVING THE POLICY FRAMEWORK IN JAPAN TO ADDRESS CLIMATE CHANGE
}

\author{
By Randall S. Jones and Byungseo Yoo ${ }^{1}$
}

Global climate change is one of the key concerns of the $21^{\text {st }}$ century, with serious environmental and economic implications. While there are significant uncertainties about the cost of inaction, it would likely be immense as sea levels rise, agricultural yields decline and infectious diseases become more prevalent. ${ }^{2}$ Indeed, climate change risks unpredictable and irreversible damage worldwide, posing sustainability challenges. Ambitious action to reduce greenhouse gas (GHG) emissions - the main driver of climate change - is therefore a priority.

Japan is active in the effort to limit climate change and increase energy efficiency. It launched an Action Programme to Halt Global Warming in 1990 and ratified the United Nations Framework Convention on Climate Change (UNFCCC) in 1993. Under the Kyoto Protocol, Japan committed to cut its GHG emissions by $6 \%$ from the 1990 base year. In June 2009, Japan announced a target of cutting its emissions by $15 \%$ from the 2005 level by 2020 through domestic reductions alone. Given that GHG emissions increased by $7.7 \%$ between 1990 and 2005, the new target implies a reduction of about $8 \%$ by 2020 from the 1990 base year. $^{3}$ This mid-term target is a step towards Japan's long-term objective of cutting its own emissions by $60 \%$ to $80 \%$ by 2050 .

$\mathrm{CO}_{2}$ emissions from energy use account for $60 \%$ of GHG emissions in the world, about $80 \%$ in developed countries and 89\% in Japan. Policies to limit GHG emissions in Japan are thus closely linked to energy efficiency. GHG emissions per capita, which can be broken down into per capita income, energy intensity and GHG emissions per unit of energy, were more than one-fifth below the OECD average in 2005 (Table 1, Column A). This reflects Japan's relatively low level of energy intensity (Column C), ${ }^{4}$ which more than offset the impact of its above-average per capita income (Column B). In addition, Japan's GHG emissions per unit of energy were also below the OECD average (Column D). The relatively good performance in 2005 was achieved despite some negative trends over the period 1990 to 2005 (Panel B).

1. Randall S. Jones is head of the Japan/Korea Desk in the Economics Department of the OECD and Byungseo Yoo is an economist on that desk. This paper initially appeared as a chapter in the OECD Economic Survey of Japan published in September 2009 under the authority of the Economic and Development Review Committee (EDRC). The authors would like to thank Andrew Dean, Alain de Serres, Jane Ellis, Jørgen Elmeskov, Robert Ford, Brendan Gillespie, Stéphanie Jamet, Vincent Koen and Masahiko Tsutsumi for valuable comments on earlier drafts. Special thanks go to Lutécia Daniel for technical assistance and to Nadine Dufour and Lillie Kee for technical preparation.

2. Recent assessments show a permanent $14.4 \%$ loss in average world consumption per capita from both market and non-market impacts (Stern, 2007).

3. Compared to 1990 (2005) levels, the mid-term goals for the EU, the United States and Japan are for emission reductions of approximately 20\% (13\%), 4\% (14\%) and 8\% (15\%), respectively. The new government made a pledge to reduce emissions by $25 \%$ compared to 1990 , conditional on an agreement on ambitious targets by all the major economies.

4. Energy intensity is affected by many non-energy factors such as climate, geography, travel distance, home size and manufacturing structure. 
Indeed, Japan's GHG emissions per capita rose $11.8 \%$ over that period, far outstripping the OECD average (Column A), despite its relatively weak economic growth (Column B). While energy intensity dropped 15.3\% in the OECD area between 1990 and 2005 (Column C) and GHG emissions per unit of energy fell 6.5\% (Column D), Japan recorded much smaller declines. Meeting its Kyoto commitment, its mid-term target and its long-term goal for emission reductions will be a difficult challenge for Japan given its emissions profile and already high level of energy efficiency.

Table 1. Decomposition of GHG emission trends ${ }^{1}$

\section{A. Level in 2005}

\begin{tabular}{|c|c|c|c|c|}
\hline & $\begin{array}{c}\text { (A) } \\
\text { GHG } \\
\text { emissions/population }^{2}\end{array}$ & $\begin{array}{c}\text { (B) } \\
\text { GDP/population }^{3}\end{array}$ & $\begin{array}{c}(\mathrm{C}) \\
\text { Energy/GDP }^{4}\end{array}$ & $\begin{array}{c}\text { (D) } \\
\text { GHG } \\
\text { emissions/energy }^{5}\end{array}$ \\
\hline Canada & 23.1 & 30.6 & 0.206 & 3.7 \\
\hline France & 8.6 & 26.5 & 0.105 & 3.1 \\
\hline Germany & 12.0 & 26.6 & 0.114 & 4.0 \\
\hline Italy & 9.7 & 25.7 & 0.096 & 3.9 \\
\hline Japan & 11.2 & 27.1 & 0.102 & 4.0 \\
\hline United Kingdom & 11.1 & 28.2 & 0.095 & 4.1 \\
\hline United States & 25.0 & 36.9 & 0.145 & 4.7 \\
\hline OECD average & 14.4 & 25.8 & 0.127 & 4.4 \\
\hline
\end{tabular}

B. Percentage change between 1990 and 2005

\begin{tabular}{lccrr}
\hline & GHG & & & \\
& emissions/population & & \\
& & GDP/population & & GHG/energy $^{5}$ \\
\cline { 2 - 5 } Canada & 8.2 & 29.7 & -15.6 & -1.2 \\
France & -4.7 & 22.1 & -9.2 & -14.0 \\
Germany & -19.0 & 21.9 & -19.8 & -17.2 \\
Italy & 9.6 & 17.3 & 3.0 & -9.3 \\
Japan & 11.8 & 16.7 & -4.0 & -0.2 \\
United Kingdom & -10.6 & 36.5 & -22.1 & -15.9 \\
United States & -0.9 & 30.8 & -21.4 & -3.5 \\
OECD total & 2.1 & 28.9 & -15.3 & -6.5 \\
\hline
\end{tabular}

\footnotetext{
1. $\mathrm{GHG}$ emissions/population $=(\mathrm{GDP} /$ population $) *($ Energy/GDP $) *(G H G$ emissions/energy $)$.

2. In $\mathrm{tCO}_{2}$ eq per head.

3. In thousand US\$ using PPP exchange rates for the year 2000

4. For total final energy consumption in ktoe/billion PPP US\$ for the year 2000 .

5. For total final energy consumption in $\mathrm{Mt} \mathrm{CO}_{2} \mathrm{eq} / \mathrm{ktoe}$. In ktoe/billion PPP US\$ for the year 2000.

Source: IEA and OECD calculations.
}

After a brief overview of Japan's policy framework, this paper analyses and assesses specific measures implemented to reduce GHG emissions. It then describes Japan's performance under this policy framework in terms of the Kyoto Protocol targets and discusses policies necessary to achieve its objectives. Policy recommendations are summarised in Box 2 at the end of the paper.

\section{Japan's policy framework to address climate change}

In 1997, the government established the Global Warming Prevention Headquarters to achieve the Kyoto Protocol target. The Prime Minister serves as chairperson, ${ }^{5}$ with all other state ministers included as members. The Kyoto Protocol Target Achievement Plan includes about 60 initiatives that are primarily

5. The priorities of environment and economic growth are balanced by having the ministers of the Environment and Economy, Trade and Industry as vice-chairs, along with the chief Cabinet Secretary. 
aimed at improving energy efficiency. The Headquarters biannually reviews progress in each sector and co-ordinates measures against climate change. In 2008, Japan announced the Action Plan for Achieving a Low-Carbon Society to support the adoption of a goal at the 2008 G8 Summit to reduce global emissions by $50 \%$ by 2050 (Box 1).

\section{Cool Earth 50 (May 2007)}

Box 1. Recent climate change initiatives in Japan

1. Launching a national campaign to achieve the Kyoto Protocol target

- Call upon the Japanese society to re-examine their lifestyles and call for new efforts and ideas to reduce GHGs, with the motto "one kilogramme per person per day".

2. Three principles to build a new framework beyond 2012

- $\quad$ Participation of all major emitters to move beyond the Kyoto Protocol to reduce global emissions.

- Adopt a flexible and diverse framework, taking into consideration the circumstances of each country.

- Achieve compatibility between environmental protection and economic growth through energy conservation and other technologies.

3. Long-term strategy

- Cut global GHG emissions by $50 \%$ from the current level by 2050 as a common goal for the whole world.

- $\quad$ Create a long-term vision of innovative technology and a low-carbon society.

Cool Earth Promotion Programme (January 2008)

1. Post-Kyoto Framework: GHG emissions must peak within 10 to 20 years and be reduced by at least half by 2050 .

- $\quad$ Create a framework in which everyone participates, including inter alia all major emitters.

- $\quad$ Set the target based on a bottom-up approach using factors such as energy efficiency on a sectoral basis and adding up the reduction potential that can be achieved based on the technology available in the future.

2. International environmental co-operation

- $\quad$ Propose a global target of improving energy efficiency by $30 \%$ by 2020.

- Establish a new financial mechanism, the "Cool Earth Partnership", on the scale of \$10 billion to support efforts to reduce emissions in developing countries.

3. Innovation

- Develop innovative technologies to promote a shift to a low-carbon society.

- Invest about $\$ 30$ billion over the next five years in R\&D in the environment and energy efficiency.

In pursuit of "Japan as a Low-Carbon Society" (July 2008)

1. Japan's mid-term and long-term goals

A) Mid-term goals

- Reduce global GHG emissions, which should peak in 10 to 20 years, and achieve a 50\% cut by 2050.

- Set quantitative national targets based on the analysis of reduction potential by applying a sectoral approach and improve global energy efficiency through technology transfer.

- Announce Japan's national target in 2009 (the mid-term target was announced in June as noted above).

B) Long-term goals

- $\quad$ Share globally the goal of reducing GHG emissions by $50 \%$ by 2050 .

- Set a goal of a $60 \%$ to $80 \%$ reduction in GHG emissions by 2050 for Japan.

2. Concrete measures (Four Pillars)

A) Develop new innovative technologies and disseminate existing advanced technologies to other countries.

- $\quad$ Contribute up to $\$ 1.2$ billion to a new multilateral fund to support efforts by developing countries.

- $\quad$ Create an International Partnership for Environment and Energy to develop innovative technologies.

- Increase use of solar energy in Japan by ten times by 2020 and by 40 times by 2030 from its current level.

- $\quad$ Convert all light bulbs from incandescent to low-energy bulbs by 2012.

- $\quad$ Promote next-generation vehicles so that they account for half of vehicles sold in 2020 .

- $\quad$ Develop systems to promote energy-efficient homes and buildings, and build housing that lasts 200 years.

B) Framework to move Japan toward a low-carbon society 


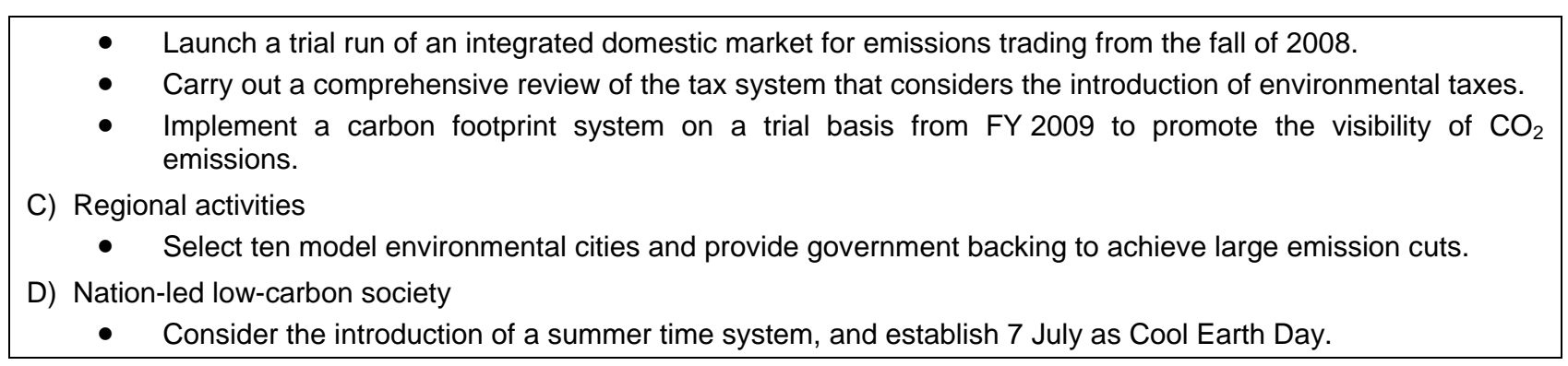

\section{Analysis of specific policy measures}

Japan's current policies can be divided into three categories; i) reducing domestic emissions through voluntary action plans, improving energy efficiency and developing renewable energy sources; ii) absorbing $\mathrm{CO}_{2}$ by increasing forest carbon sinks; and iii) obtaining emission credits through the Kyoto mechanisms, including the Clean Development Mechanism (CDM). This section evaluates the results of these policies.

\section{Reducing domestic emissions}

\section{Voluntary action plans}

In 1997, Keidanren (Japan Business Federation) established the Voluntary Action Plan (VAP) on the Environment, which set a target of keeping $\mathrm{CO}_{2}$ emissions in FY 2010 below their FY 1990 level. The 35 industrial organisations (such as the Iron and Steel Federation, which has 134 firms) that participate in this initiative accounted for $84 \%$ of the total amount of $\mathrm{CO}_{2}$ emitted by the industrial and energy conversion sectors and 45\% of Japan's total $\mathrm{CO}_{2}$ emissions in FY 1990. Progress is reviewed annually by Keidanren as well as by the government and NGOs. By 2006, overall $\mathrm{CO}_{2}$ emissions had decreased by $1.5 \%$ from the 1990 level, although this partly reflected a modest increase in production of only $12 \%$ over that period. As a result, 17 organisations increased their reduction targets for the following year. In a separate initiative, industrial organisations, including some that are not affiliated with Keidanren, announced their own GHG reduction objectives. As of March 2008, 54 organisations in the industrial and energy conversion sector, 17 in the transport sector and 32 in other sectors, primarily services, had established measurable targets and their performance was monitored by the government and NGOs.

Japan's efforts to cut domestic emissions through voluntary measures have thus had some positive results. The advantage of voluntary agreements, which are also used in some other OECD countries, ${ }^{6}$ is to avoid procedural costs for government and industry and to provide favourable publicity to firms, thus encouraging them to participate. In Japan, monitoring by the government and NGOs and social pressure encourages compliance with voluntary targets, leading to reductions in the industrial sector. ${ }^{7}$ However, a voluntary approach is not cost-effective, as the marginal cost of abatement is likely to differ between emitters, and does not provide adequate incentives to motivate emitters to innovate and find abatement

6. Australia's “Greenhouse Challenge Plus” programme: An agreement between the government and an enterprise/industry association to reduce GHG emissions. Netherlands Voluntary Agreement on Energy Efficiency: A series of legally binding long-term agreements based on annual improvement targets and benchmarking covenants between 30 industrial sectors and the government to improve energy efficiency. United States Climate Leaders: a 2002 partnership that encourages individual companies (188 at present) to develop corporation-wide GHG inventories, set aggressive reduction goals, report inventory data annually, document progress towards their goals and report annually to the US Environmental Protection Agency.

7. Such pressure prompted the steel and electricity industries to purchase Kyoto credits to meet their targets. 
options beyond their voluntary agreements that are large enough to meet the Kyoto Protocol targets. Firms may use their informational advantages over policy makers to target emission reductions equal to what would have been achieved in any case. Moreover, a voluntary approach cannot cope effectively with risk and uncertainty (Duval, 2008). Japan should shift policies to combat climate change to market instruments in order to achieve long-term goals in a cost-effective way.

\section{The creation of a voluntary emissions trading system}

Japan's Voluntary Emissions Trading System (JVETS) was launched in 2005 to gain experience with emission trading. For participating firms, one-third of the cost of new facilities to reduce emissions is borne by the government, which is an incentive for firms to join JVETS as such facilities also tend to reduce their energy costs. Firms that fail to achieve their objective must purchase credits from firms that have achieved larger-than-targeted reductions or return the subsidy to the government. ${ }^{8}$ The system now includes 199 firms that voluntarily pledge to reduce emissions relative to their average during the previous three years. In FY 2007, the committed reduction was $21 \%$ below this baseline and, in the event, a $29 \%$ cut was achieved. However, the JVETS is at an early stage. The participating firms account for less than $1 \%$ of $\mathrm{CO}_{2}$ emissions from the industrial sector and they are allowed to set their own targets for emission reductions. In FY 2007, there were only 51 transactions with a total value of 68 million yen ( $\$ 0.7$ million).

In October 2008, the government launched a trial emissions trading system (ETS) that includes the JVETS as an option. The targets of the trial ETS are not ambitious, as the main objective is to gain experience in using an ETS system. After an intensive recruitment process, 715 firms, including 521 firms with targets accounting for about two-thirds of $\mathrm{CO}_{2}$ emissions by the industrial sector, agreed to participate. Firms already part of the Keidanren's VAP set their targets in line with their individual VAP commitment, while the other firms use the target-setting method of the JVETS. The trial ETS allows participants to use Kyoto mechanism credits (see below) and domestic crediting mechanisms, which permit them to claim the $\mathrm{CO}_{2}$ reductions achieved through their joint efforts with small and medium-sized enterprises (SMEs). Credits are created when SMEs achieve lower emissions, relative to their estimated emissions based on a business as usual approach, using technology and finance provided by large firms.

Firms that fail to achieve their targets face no penalties, although the JVETS participants have to return their subsidies to the government. This voluntary approach reflects concerns in part of the business community, which opposes the idea of mandatory caps on emissions on the grounds that it would hinder economic growth and impede corporate activity. However, it is clear that companies will eventually have to make deep cuts in their emissions in order to achieve Japan's Kyoto objective and its medium and longrun GHG reduction targets.

\section{Top Runner Programme to improve energy efficiency}

The Top Runner Programme aims at upgrading the energy efficiency of a variety of products to the highest level possible. The government finds the most efficient model on the market and then uses that as the basis for discussions with producers to set a target for energy efficiency within a certain number of years. In many countries, in contrast, the energy efficiency of products is subject to minimum efficiency performance standards (OECD, 2006). ${ }^{9}$ This Programme started in 1999 with ten product categories and

8. The budget to operate the JVETS is around 3 billion yen ( $\$ 32.6$ million) per year. With 150 firms participating, the average subsidy per firm is 200 million yen ( $\$ 2.2$ million).

9. As of 2005 , at least 51 countries, including the EU's then 25 member states, had established Minimum Efficiency Performance Standards (MEPS) for household appliances and office equipment. Most of these countries are developed countries, although a number of less developed countries have established similar standards. An additional 26 countries are in the process of preparing MEPS (OECD, 2006). 
has expanded to 23 . The scheme imposes two legal obligations on manufacturers and importers to achieve technological advances. First, they are required to provide information about the end-use energy performance of their products. Second, they must prove that the weighted average energy performance of the products they sell in the target year meets the standard. The Ministry of Economy, Trade and Industry can disclose the names of companies that fail to meet the target, as well as issue recommendations, orders and fines. To date, no enforcement actions have been taken, as every producer has been found to meet or exceed the target (Figure 1). According to one study (Ito, 2007), the introduction of the Programme has reduced energy consumption by $5 \%$ in road transport and by $8 \%$ in the residential sector.

Figure 1. Target and performance of the Top Runner Programme ${ }^{1}$

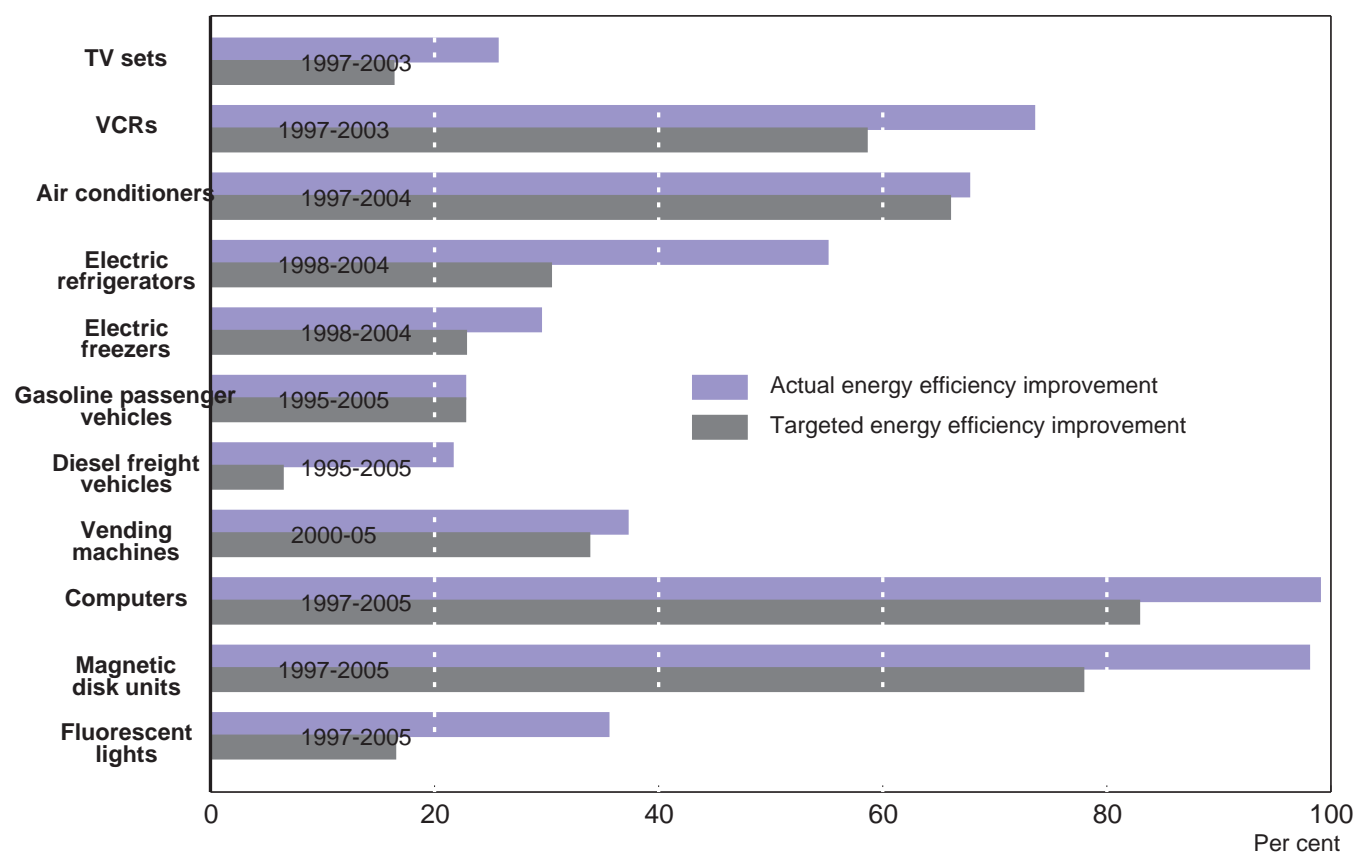

1. The energy efficiency standard is defined in terms of kilometres per litre for vehicles and kWh/year for electronic appliances. The "energy efficiency improvement" shows the change in this indicator. For example, if energy efficiency increased from 10 kilometres per litre to 15 , that would be a $50 \%$ improvement.

Source: Energy Conservation Centre (2008).

The positive impact of the Top Runner Programme is a result of several factors (Nordqvist, 2006). First, the producers subject to the regulation are themselves involved in setting targets, resulting in high levels of awareness and commitment and ensuring that the targets are feasible. Second, "name-and-shame" sanctions are effective deterrents in Japan, prompting companies to make considerable efforts to achieve the targets. The Programme is effective because it puts the brand image of a company at risk. Third, energy efficiency is perceived as a competitive advantage, making manufacturers supportive of the Programme's objectives. Fourth, the markets covered by the Programme are dominated by domestic actors, reducing the risk of objections from stakeholders outside Japan.

Despite some success, there is room to strengthen the Top Runner Programme, particularly with respect to target-setting, the scope of coverage, interim reporting and evaluation (Nordqvist, 2006 and OECD, 2008c).

- Generally, the most common critique of the target approach is that its focus on "realistic" levels of energy efficiency encourages only incremental improvements, while giving no incentives for 
breakthrough innovations. In particular, firms with the most energy-efficient products at the start of a target cycle do not need to invest to achieve additional efficiency gains during the compliance period. Strengthening incentives for the "top runners" is necessary to promote breakthrough technological advancements.

- Some products covered by energy efficiency standards in other countries are not included in the Top Runner Programme. One key priority would be residential and commercial heating, which accounts for about $12 \%$ of total energy consumption. Japan should extend its coverage to include other residential and commercial products, as well as industrial and transport products that use significant amounts of energy while phasing out the Programme as market-based instruments become effective.

- The performance under the Top Runner Programme is usually evaluated in the target year. To accelerate efforts for energy efficiency, it would be helpful to evaluate and publish results even before the target is mandatory.

- The financial and economic costs and benefits of the Programme should be analysed.

\section{Development of renewable energy sources}

The share of renewable energy in the total primary energy supply in Japan was only $3.2 \%{ }^{10}$ in 2006 , half of the OECD average of $6.3 \%$ (Figure 2) and the sixth lowest in the OECD area. Moreover, its share declined from $3.4 \%$ in 1990 to $3.2 \%$ in 2006, while the share in the OECD area increased from 5.8\% to $6.3 \%$ over the same period. It should be noted that the potential for renewables in each country depends on a number of factors, including geography. Japan's low share reflects the limited amount of energy generated by renewable combustibles and waste. In contrast, it plays a larger role in solar energy: in 2006, Japan produced more than half of the world's solar panels, and ranked second in the world in generating energy by photovoltaic facilities, with almost one-third of the total.

In 2009, Japan set a target to increase the share of renewable energy to $20 \%$ of total primary energy supply by 2020 to help achieve its mid-term emission reduction objective. ${ }^{11}$ In particular, for photovoltaic generation, a twenty-fold increase from its 2005 level is expected by 2020. To achieve this goal, a number of policies are aimed at reducing the price of such systems by half within three to five years through technological innovation and demand creation to exploit economies of scale. Although setting long-term targets for other renewable energy sources would encourage private-sector investment in these areas, it is not a cost-effective approach. Instead, the authorities should develop transparent and efficient instruments to support the development and use of renewable energy in the short run, while relying on the correct pricing of GHG emissions to achieve the optimal share of renewables in the long run.

10. According to the official energy balance of Japan, the ratio of total renewable energy in primary energy supply was $6.2 \%$ in 2006 .

11. This would represent a three-fold increase from its $6.2 \%$ share in 2006 using the Japanese calculation method. 
Figure 2. Energy sources in the OECD area in $2006^{1}$
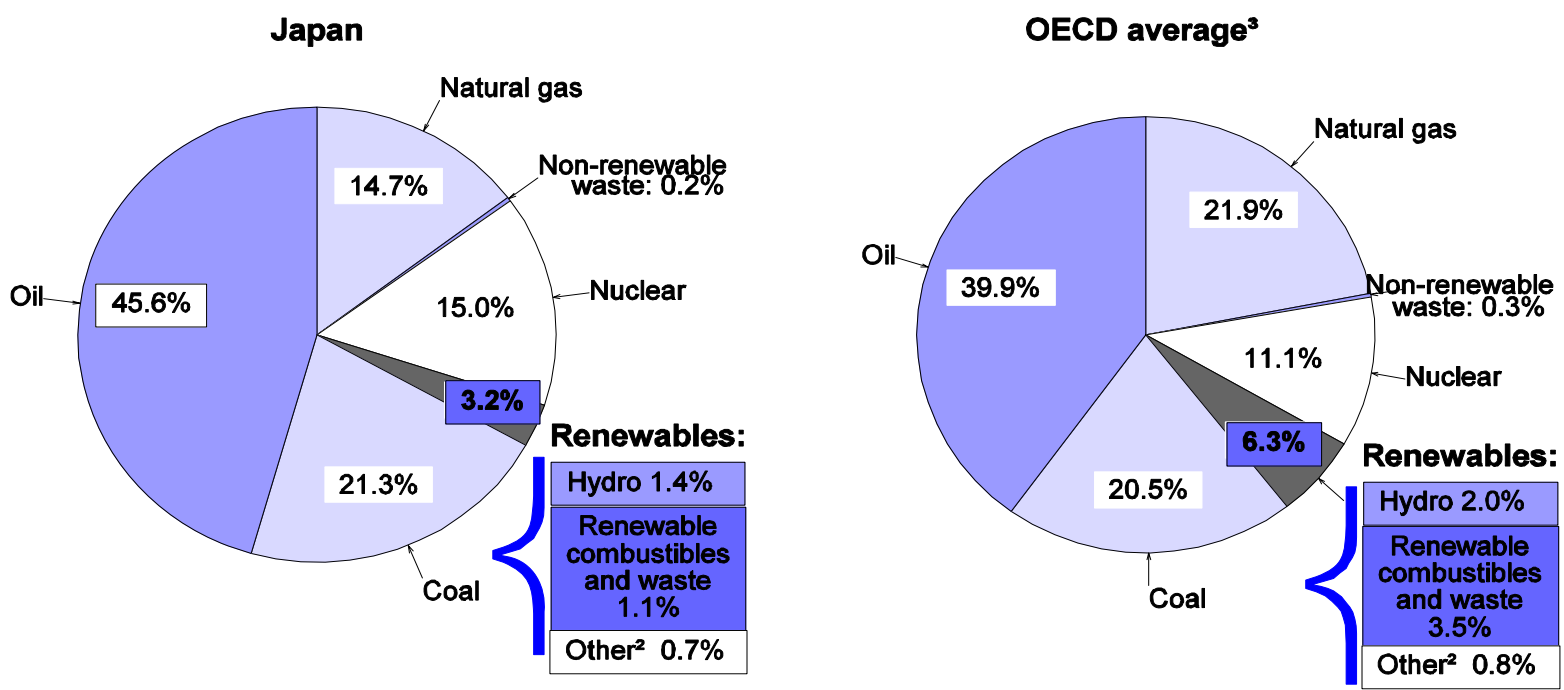

1. As a share of total primary energy supply.

2. Geothermal, wind, solar and tide.

3. Excludes Iceland, Mexico and Portugal.

Source: OECD (2008e), Renewables Information, OECD, Paris and IEA/OECD (2008), Energy Balances of OECD Countries, Paris.

The share of renewable energy sources in generating electricity in Japan fell from over $20 \%$ in the 1970 s to about $10 \%$ in 2006 , well below the OECD average of $15 \%$. The declining share reflects the fact that electricity from hydro lagged behind the overall growth of electricity generation. Nevertheless, hydro still had the largest share of renewable generation at 79\%, followed by biomass (17\%), geothermal (3\%) and wind (2\%). ${ }^{12}$ The 2003 Renewable Portfolio Standard (RPS) established procurement quotas to increase the volume of electricity generated from renewable energy sources (excluding hydro) from 7.3 billion $\mathrm{kWh}$ in 2003 to 12.2 billion $\mathrm{kWh}$ in 2010 (which is equivalent to around $1 \%$ of total electricity generation). In 2007, a target of 16 billion $\mathrm{kWh}$ was set for 2014. The annual goals have been easily achieved during the first few years, as the objective in 2006 was below the actual share of renewable energy in 2004. However, achieving the target is becoming more challenging each year. The RPS appropriately does not specify which renewable sources are to be increased, thus allowing a cost-effective expansion to meet the overall goal. Utilities can meet their obligations by trading with other utilities. Encouraging such trading would limit the excess cost paid by consumers to achieve the 2014 target, which may amount to 130 billion yen ( $\$ 1.4$ billion). Boosting the use of renewable energy depends in part on technological advances, an area where Japan is strong. Although total R\&D outlays on energy fell slightly between 1996 and 2006, Japan's R\&D on renewables more than doubled over that period (OECD, 2008c).

A related goal in the 2008 Action Plan for Achieving a Low-Carbon Society is to increase the proportion of electricity from zero-emission sources, notably renewable and nuclear, from $40 \%$ in 2006 to over $50 \%$ by around 2020 . Power generation from nuclear plants accounted for $28 \%$ of total electricity and $11 \%$ of total primary energy supply in 2006 . With 53 operating nuclear plants, Japan is the thirdlargest user of nuclear power in the world. The plan to construct 13 additional nuclear power plants, of which nine are to be completed by 2017, will help meet the 2020 target.

12. OECD (2008c). Electricity from wind and solar, whose share is near zero, is understated as the data only cover plants with capacity of at least $1000 \mathrm{~kW}$. The net generating capacity of photovoltaics was $3.3 \%$ in 2006. 
One of the major sources of renewable energy is biomass. The government is promoting the utilisation of this energy source to address climate change and to promote the development of agriculture and forestry, based on the revised 2006 "Biomass Nippon Strategy", which includes the establishment of 300 "Biomass Towns" that will rely extensively on biomass. By July 2009, 218 towns had been recognised. In 2007, the government announced a roadmap aimed at increasing the annual production of biofuels (ethanol and diesel) from the 2006 level of around 5000 to 60000 kilolitres within a few years. However, the high cost of biofuels suggests some caution in promoting this energy source. Indeed, the cost of support to biofuels is estimated at between $\$ 960$ and $\$ 1700$ per tonne of $\mathrm{CO}_{2}$ saved in the United States, Canada and the European Union, according to a recent study (OECD, 2008a), compared to the price of $\$ 15$ to $\$ 30$ price per tonne in the EU ETS.

\section{Making the tax system greener}

A number of reforms have been introduced recently to make the tax system more environmentallyfriendly: $i)$ the motor vehicle tonnage tax and the automobile acquisition tax were reduced or exempted in 2009 for environment-friendly automobiles until 2012; ii) the automobile tax was cut by $25 \%$ to $50 \%$ depending on a vehicle's environmental performance; iii) households were given tax credits for energysaving measures, including solar panels; and iv) firms are allowed to take immediate depreciation on investment in facilities that produce energy-saving products, such as solar panels, until 2011. These measures provide reductions in personal or corporate income taxes to encourage energy-saving measures. However, tax breaks to subsidise environment-friendly activities are a poor substitute for taxing activities with negative externalities. Revenues from environmental taxes, which increase the cost of using energy and environmentally-harmful products, were only $1.7 \%$ of GDP in 2006, the sixth lowest in the OECD area (Figure 3) and well below the (unweighted) average of 2.3\%. ${ }^{13}$ Moreover, the share of environmental taxes has stayed around the same level for a decade. In the 2008 Action Plan for Achieving a Low-Carbon Society, the government stated that it would review the entire tax system, including environmental taxes, with a goal of reducing carbon emissions. Increasing environmental taxes in the fundamental tax reform planned for FY 2011 would not only reduce energy use and emissions but also help meet demands for more tax revenue, ${ }^{14}$ although some could be used to increase public R\&D on energy conservation.

\section{Forest carbon sinks}

Forests, which cover about two-thirds of Japan, are an important source of carbon reduction. Forest carbon sinks ${ }^{15}$ in the context of the Kyoto Protocol removed a net total of 37 million tonnes of $\mathrm{CO}_{2}(2.7 \%$ of Japan's total emissions) in 2006. The Kyoto Protocol Target Achievement Plan implies that forest carbon sinks are expected to account for 3.8 percentage points of the $15 \%$ reduction needed to achieve Japan's overall reduction target (see below). Enhanced forest management practices are necessary, given that $65 \%$ of managed forests are still immature according to the Forestry Agency. The government launched a programme in 2007 that includes subsidies to help private owners of forest land (who own 58\% of the total) improve the condition of their forests. The Forestry Agency estimates that an additional 0.2 million hectares of properly managed forest will be required each year between 2007 and 2012 in order to achieve Japan's goal for $\mathrm{CO}_{2}$ reduction by forest carbon sinks.

13. However, it was above the OECD weighted average of $1.6 \%$, which reflects the US figure of $0.9 \%$.

14. The supplementary provision of the Tax Revision Act of FY 2009 included greening of the whole tax system as an element in the future reform of the tax system.

15. A carbon sink is a natural or manmade reservoir that accumulates and stores some carbon-containing chemical compound for an indefinite period. 
Figure 3. Revenues from environmental taxes

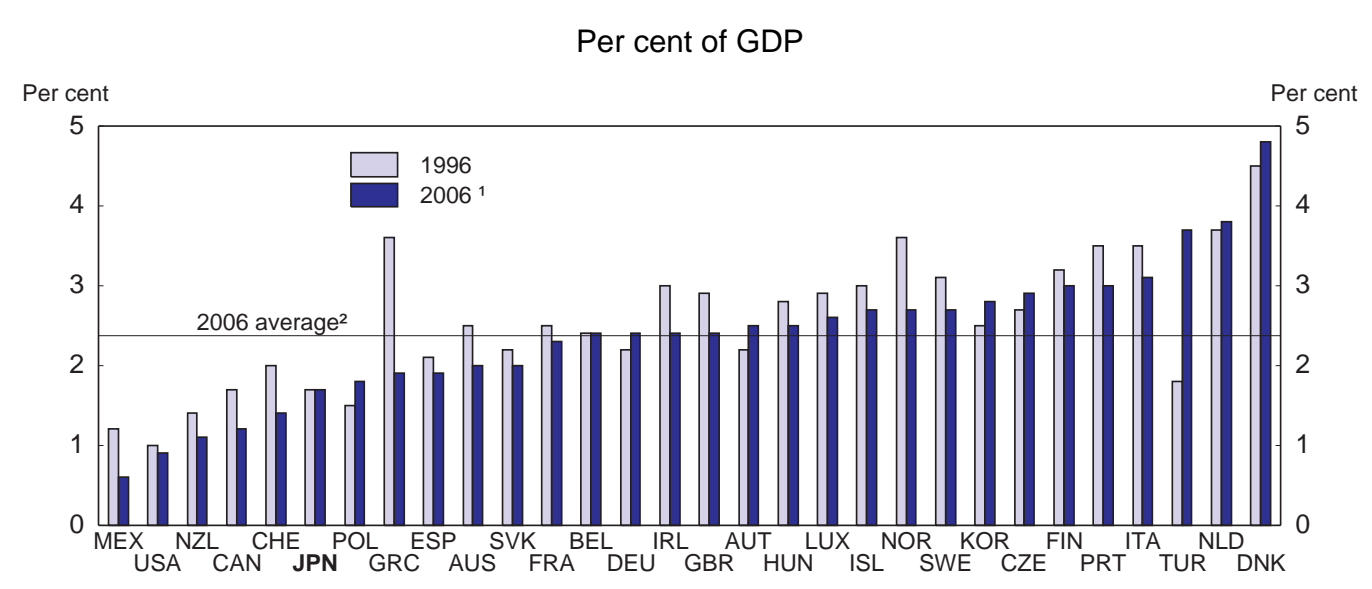

1. For France, 2004 and for Belgium and the Netherlands, 2005.

2. Arithmetic average. The weighted average is $1.6 \%$.

Source: OECD/EEA, Database on instruments used for environmental policy.

Deforestation, primarily in developing countries, is estimated to account for up to $17 \%$ of global GHG emissions in recent years (IPCC, 2007). Reducing emissions from deforestation and forest degradation (REDD) could potentially lower the cost of reducing GHG (Burniaux et al., 2009). Monitoring and providing financial incentives to developing countries for REDD requires incorporating forestry in an international agreement for a post-2012 framework. Japan's monitoring technologies for forests and willingness to participate in partnerships with developing countries would be helpful in this regard. ${ }^{16}$

\section{The Clean Development Mechanism and other Kyoto mechanisms}

The Kyoto Protocol introduced three mechanisms - emissions trading, the Clean Development Mechanism (CDM) and Joint Implementation (JI) ${ }^{17}$ - which together constitute the official international carbon market. These market-based mechanisms help countries meet their Kyoto commitments by reducing emissions or removing carbon from the atmosphere in a cost-effective way (both domestically and in other countries), stimulating sustainable development through technology transfers and investment and encouraging the private sector and developing countries to reduce emissions. Japan has purchased emission credits from the international market since 2004 to offset domestic emissions. The government expects the Kyoto mechanisms to account for 1.6 percentage points of the $15 \%$ reduction needed to meet the Kyoto target (see below). The CDM, which is the most used of the three mechanisms, generates credits from projects that reduce emissions in developing countries. The "certified emission reductions" (CERs) from these projects can be used by developed countries to meet their own emission targets, while helping developing countries achieve sustainable development. Japan, as a relatively energy-efficient economy, has large scope to use the Kyoto mechanisms to achieve its emission reduction obligation in a cost-effective way. As of April 2009, Japan was the fourth-largest buyer of CDM credits with 199 projects, $11 \%$ of the total number.

16. For example, Japan is currently supporting forest resource management in Indonesia by transferring monitoring technologies using satellite images. Japan also made a \$10 million contribution to the Forest Carbon Partnership Facility, a fund for assisting forest conservation activities in developing countries.

17. Like the CDM, JI is a project-based mechanism that feeds the carbon market by enabling industrialised countries to carry out joint implementation projects with other developed countries. 
The New Energy and Industrial Technology Development Organisation (NEDO) has been commissioned by the Japanese government to acquire CERs and other types of emission reduction credits. The NEDO purchased credits for 55 million tonnes of $\mathrm{CO}_{2}$ emission reductions by the end of FY 2008. In addition, Japan Carbon Finance Limited, established in 2004, uses money supplied by the Japan Greenhouse Gas Reduction Fund (JGRF) to develop GHG reduction projects and to purchase emission credits. The JGRF was established in 2004 by a total of 33 entities, including private firms and two government banks. By June 2008, Japan Carbon Finance had purchased credits for 18.5 million tonnes of $\mathrm{CO}_{2}$ reductions, which are then distributed to the investors in the JGRF.

Japan has made efforts to promote effective use of its official development assistance (ODA) to acquire credits under the CDM. In the creation of the CDM in 2001, it was agreed "that public funding for clean development mechanism projects... is not to result in the diversion of ODA". Such diversion, which can occur in financial, sectoral and regional terms, risks reducing investment in infrastructure projects in developing countries. CDM projects, in line with market principles, have thus far been concentrated in more advanced developing countries that have greater potential to reduce emissions, in contrast with ODA's primary objective of promoting the economic development of the poorest countries. Indeed, lowermiddle and low-income countries, which receive $82.3 \%$ of Japanese ODA, were host for only $13.9 \%$ of Japan's CDM projects (Table 2). Three of the top ten ODA recipients did not receive any CDM projects, while relatively high-income countries, such as Brazil, Korea and Chile, had large shares (Panel B). Moreover, CDM projects are relatively concentrated, with China alone accounting for two-thirds of total emission reductions from CDM projects and the top eight host countries accounting for more than $90 \%$.

The OECD's Development Assistance Committee, which is responsible for compiling statistics on ODA, reached an agreement in 2004 that the value of emission credits received in connection with ODAfinanced CDM projects should be deducted from ODA. In 2007, a Japanese loan for a project in Egypt was registered as the world's first large-scale CDM project directly assisted by bilateral ODA. The CDM Executive Board ${ }^{18}$ agreed on the condition that the emission credits generated by this project were bought by a private firm in Japan and that the public funding for CDM projects would not result in the diversion of ODA. The Japanese government plans to continue to promote CDM by utilising ODA.

\section{Japan's performance under the Kyoto Protocol}

As noted above, Japan agreed to reduce its GHG emissions by $6 \%$ relative to the 1990 base year over the period 2008-12 (Figure 4). However, emissions were up by $9 \%$ by 2007 , indicating that the diverse set of measures discussed above have failed to reduce emissions as envisaged under the Kyoto Protocol. The overall increase was explained by a rapid rise in the commercial and residential sectors. In addition, there was a fall in the capacity utilisation rate for nuclear power plants, from $73 \%$ in 1990 to $61 \%$ in $2007,{ }^{19}$ due in part to natural disasters, which also caused a decrease in hydroelectric power generation. The $15 \%$ reduction from the 2007 level is to be achieved through cuts in domestic emissions $(9.6 \%)$, forest carbon sink measures (3.8\%) and the Kyoto mechanisms, including CDM (1.6\%). Meeting the Kyoto commitment is a challenging objective, given the rise in emissions over the past decade. However, the deep recession, which the government projects will reduce industrial production by $24 \%$ in FY 2009, will have a large impact on $\mathrm{CO}_{2}$ emissions, given that industry accounts for $40 \%$ of all emissions. In addition, falling consumption tends to cut emissions by the household and transport sectors. However, the prospect of an economic recovery suggests that some of the reductions could be only temporary. It is important, therefore, for Japan to reduce its emissions by improving its policy framework, in particular to meet the mid-term target for 2020 .

18. The Board consists of ten members and ten alternates elected by the Conference of Parties.

19. The utilisation rate peaked at $84 \%$ in 1998 . 
Table 2. Overseas Development Assistance and the Clean Development Mechanism

A. ODA recipients ${ }^{1}$ and Japanese CDM projects ${ }^{2}$ by host country grouped by income levels

\begin{tabular}{|c|c|c|c|c|c|}
\hline \multicolumn{2}{|c|}{ Income level $^{3}$} & \multicolumn{2}{|c|}{$\begin{array}{c}\text { ODA } \\
\text { (in per cent) }\end{array}$} & \multicolumn{2}{|c|}{$\begin{array}{c}\text { CDM } \\
\text { (in per cent) }\end{array}$} \\
\hline \multirow{2}{*}{\multicolumn{2}{|c|}{$\begin{array}{l}\text { High-income countries } \\
\text { Upper-middle income countries }\end{array}$}} & \multicolumn{2}{|c|}{0.0} & \multicolumn{2}{|c|}{6.5} \\
\hline & & \multicolumn{2}{|c|}{6.5} & \multicolumn{2}{|c|}{13.5} \\
\hline \multicolumn{2}{|c|}{ China } & \multicolumn{2}{|c|}{11.2} & \multicolumn{2}{|c|}{66.1} \\
\hline \multicolumn{2}{|c|}{ Lower-middle income countries } & \multicolumn{2}{|c|}{38.4} & \multicolumn{2}{|c|}{4.6} \\
\hline \multirow{2}{*}{\multicolumn{2}{|c|}{ Low-income countries }} & \multirow{2}{*}{\multicolumn{2}{|c|}{$\begin{array}{r}43.9 \\
100.0\end{array}$}} & \multirow{2}{*}{\multicolumn{2}{|c|}{$\begin{array}{r}9.3 \\
100.0\end{array}$}} \\
\hline & & & & & \\
\hline \multicolumn{6}{|c|}{ B. Top ten recipients of ODA ${ }^{1}$ and Japanese CDM credits by host country ${ }^{2}$} \\
\hline $\begin{array}{c}\text { Top ten ODA } \\
\text { recipients }\end{array}$ & $\begin{array}{c}\text { Per cent } \\
\text { of total }\end{array}$ & $\begin{array}{l}\text { Per cent of } \\
\text { CDM }\end{array}$ & Top ten recipients of $\mathrm{CDM}^{2}$ & $\begin{array}{l}\text { Per cent } \\
\text { of total }\end{array}$ & $\begin{array}{l}\text { Per cent of } \\
\text { ODA }\end{array}$ \\
\hline China & 11.2 & 66.1 & China & 66.1 & 11.2 \\
\hline Nigeria & 9.6 & 0.0 & Brazil & 6.6 & 0.7 \\
\hline Indonesia & 9.3 & 2.0 & Korea & 6.5 & 0.0 \\
\hline Iraq & 7.6 & 0.0 & India & 3.2 & 5.5 \\
\hline Philippines & 6.6 & 0.4 & Chile & 3.2 & 0.1 \\
\hline Vietnam & 6.4 & 0.8 & Uzbekistan & 2.3 & 0.5 \\
\hline India & 5.5 & 3.2 & Indonesia & 2.0 & 9.3 \\
\hline Tanzania & 3.4 & 0.0 & Malaysia & 1.6 & 2.8 \\
\hline Malaysia & 2.8 & 1.6 & Vietnam & 0.8 & 6.4 \\
\hline Sri Lanka & 2.7 & 0.1 & Thailand & 0.7 & 1.9 \\
\hline Total & 65.1 & 74.1 & Total & 92.9 & 38.3 \\
\hline
\end{tabular}

1. Percentage of total Japanese ODA (excluding the portion that is not allocated to specific countries) during the period 2006-07.

2. All projects registered as of April 2009. When a project is financed by more than one country, Japan's share is estimated by the total emission reduction divided by the number of countries.

3. As defined by the World Bank. Per capita income is above $\$ 11116$ in high-income countries, $\$ 3596$ to $\$ 11115$ in upper-middle income countries, \$906 to \$3595 in lower-middle income countries and below \$905 in low-income counties. China is classified as a lower-middle income country.

Source: Clean Development Mechanism and OECD.

Table 3. Carbon intensity and $\mathrm{CO}_{2}$ emissions per capita

\begin{tabular}{|c|c|c|c|c|c|c|c|c|c|c|}
\hline & \multicolumn{5}{|c|}{$\mathrm{CO}_{2}$ emissions/GDP $(\mathrm{Kg}, \mathrm{USD})^{1}$} & \multicolumn{5}{|c|}{$\mathrm{CO}_{2}$ emissions/population (tonnes) } \\
\hline & 1971 & 1990 & 2000 & 2006 & $\begin{array}{c}\text { Cumulative change } \\
1990-2006(\%)\end{array}$ & 1971 & 1990 & 2000 & 2006 & $\begin{array}{c}\text { Cumulative change } \\
1990-2006(\%)\end{array}$ \\
\hline World & 0.81 & 0.63 & 0.52 & 0.49 & -23.3 & 3.75 & 3.99 & 3.87 & 4.28 & 7.4 \\
\hline OECD total & 0.81 & 0.53 & 0.46 & 0.41 & -22.0 & 10.59 & 10.62 & 11.07 & 10.93 & 2.9 \\
\hline OECD N. America & 1.05 & 0.67 & 0.57 & 0.50 & -25.4 & 16.91 & 15.56 & 16.00 & 15.21 & -2.2 \\
\hline OECD Pacific & 0.58 & 0.42 & 0.43 & 0.40 & -5.5 & 6.30 & 8.46 & 10.13 & 10.55 & 24.6 \\
\hline Japan & 0.58 & 0.37 & 0.37 & 0.34 & -8.3 & 7.24 & 8.68 & 9.40 & 9.49 & 9.4 \\
\hline OECD Europe & 0.69 & 0.44 & 0.36 & 0.33 & -26.2 & 8.12 & 7.86 & 7.55 & 7.60 & -3.4 \\
\hline Non-OECD total & 0.71 & 0.76 & 0.57 & 0.54 & -29.9 & 1.48 & 2.20 & 2.06 & 2.64 & 19.9 \\
\hline China & 1.72 & 1.15 & 0.60 & 0.63 & -44.7 & 0.96 & 1.97 & 2.42 & 4.28 & 117.8 \\
\hline
\end{tabular}

1. Converted at 2000 PPP exchange rates. Using market exchange rates, Japan's intensity in 2006 was 0.24 , compared with an OECD average of 0.44 .

Source: IEA/OECD (2008), $\mathrm{CO}_{2}$ Emissions from Fuel Combustion, Paris. 
Figure 4. Overview of the Kyoto and mid-term emission targets in Japan

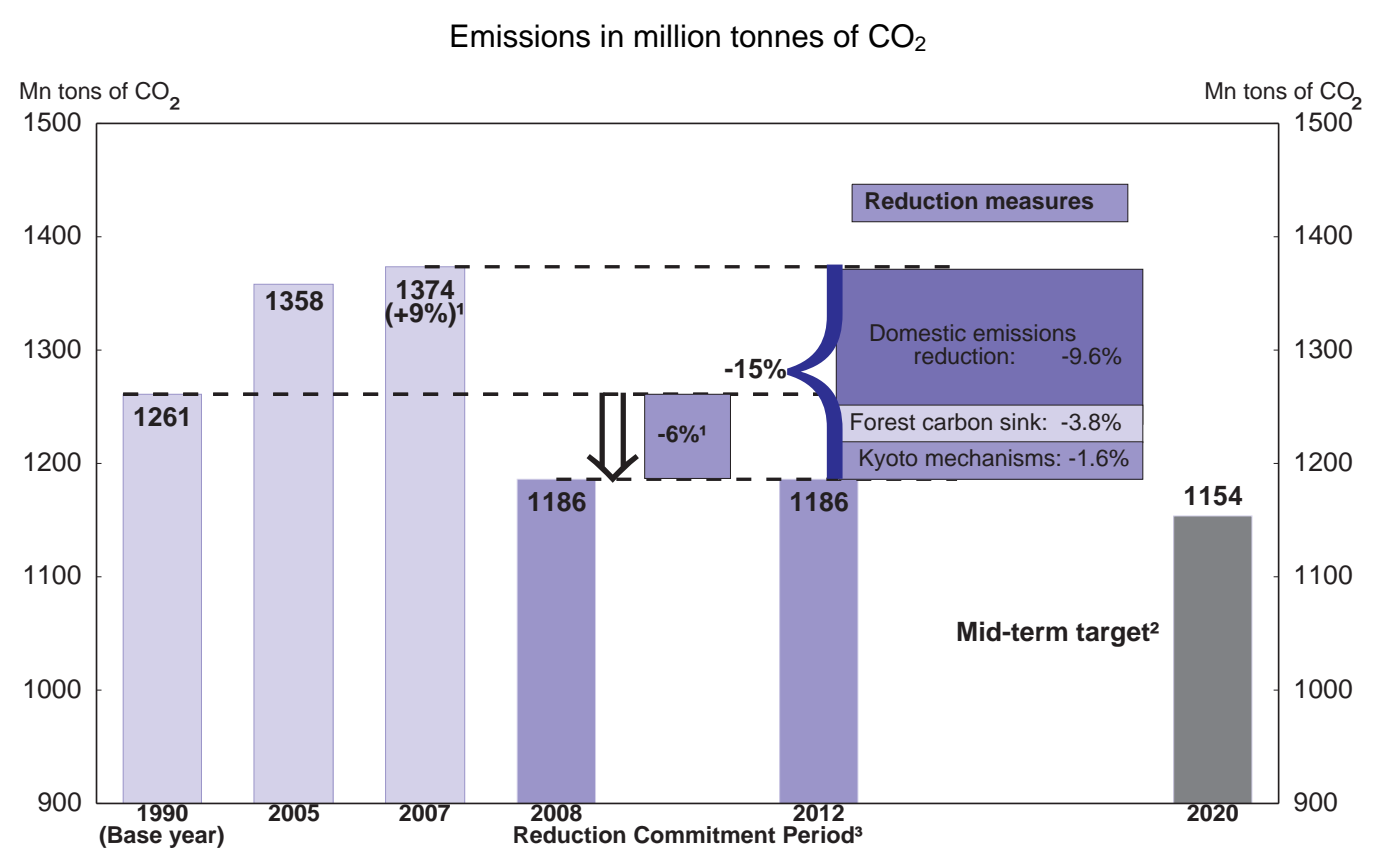

1. Percentage change relative to the 1990 base year.

2. The mid-term target of a $15 \%$ decline by 2020 , through domestic reductions alone, from the 2005 level of emissions, implies a fall in emissions to $1154 \mathrm{Mn}$ tonnes.

3. Japan is committed to reducing GHG emissions by $6 \%$ relative to the 1990 base year under the Kyoto Protocol. The $15 \%$ decline is calculated as the $9 \%$ increase between 1990 and 2007 and the $6 \%$ decline.

Source: Ministry of the Environment.

Japan is the world's second-largest economy and the fifth-largest emitter of $\mathrm{CO}_{2}$, accounting for $4.3 \%$ of the global total (Figure 5). Its carbon intensity $\left(\mathrm{CO}_{2}\right.$ emissions per unit of GDP) was almost one-fifth below the OECD average in 2006 (Table 3). Given its low carbon intensity, the marginal cost of further reductions in $\mathrm{CO}_{2}$ emissions is higher in Japan than in other countries. These international comparisons also reveal that OECD Europe has achieved a slower pace of growth in emissions since 1990 (Figure 5, Panel B), reducing its carbon intensity below Japan's by 2006 (Table 3). In per capita terms, the picture is similar; Japan's $\mathrm{CO}_{2}$ emissions are still below the OECD average but they increased by $9.4 \%$ between 1990 and 2006, in contrast to declines recorded in OECD Europe (-3.4\%) and North America (-2.2\%).

The rise in $\mathrm{CO}_{2}$ emissions in Japan between 1990 and 2007 is largely accounted for by the commercial and residential sectors, where they increased by $44 \%$ and $41 \%$, respectively (Figure 6 ). The former reflects a $39 \%$ expansion in office floor space over that period. As for the residential sector, the number of households jumped $26 \%$, even though total population rose only $3 \%$, while ownership of electrical appliances increased. Growing energy use in the commercial and residential sectors suggests a need for more efforts in this area, in particular by improving the energy performance of buildings. In 2008, the Act on the Promotion of Global Warming Countermeasures was broadened to include the residential and commercial sectors. Emissions are to be limited through comprehensive plans by prefectures and certain major cities and reports from businesses and franchises, but there is no enforcement mechanism to ensure that the plans are achieved. In sum, it is important to reverse the upward trend in the emissions of the commercial and residential sectors, which account for about one-third of the total (Panel B). At the same time, further reductions are needed in the industrial sector, which accounted for $38.6 \%$ of emissions in 2007. 
Figure 5. International comparison of $\mathrm{CO}_{2}$ emissions

A. Share of world $\mathrm{CO}_{2}$ emissions in 2006

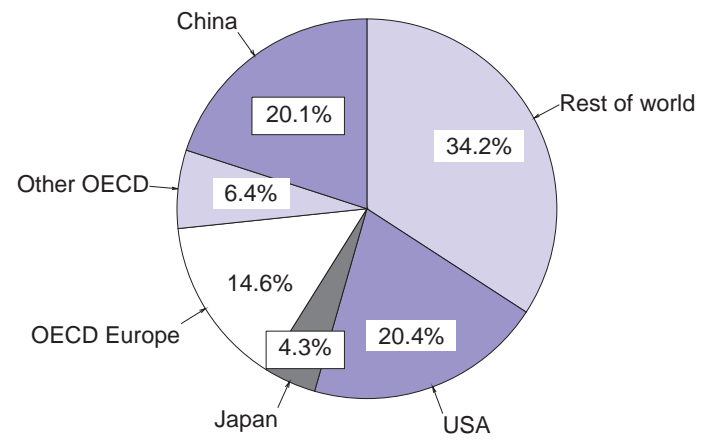

B. Growth in $\mathrm{CO}_{2}$ emissions between 1990 and 2006

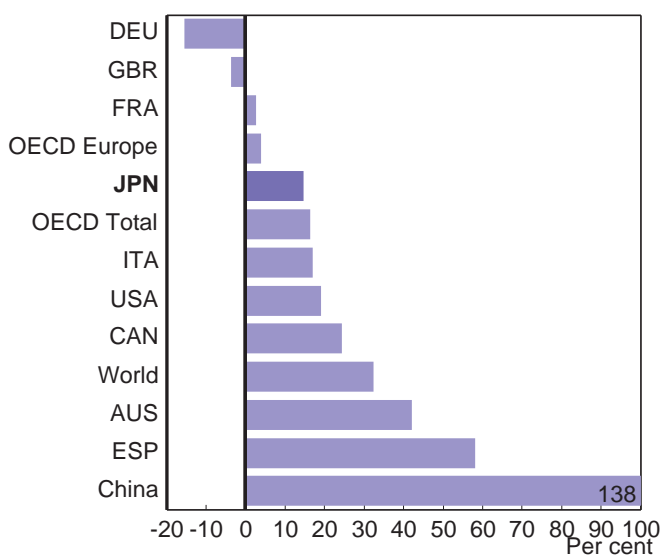

Source: OECD, Environmental Database.

One of the benefits from cutting GHG emissions is the accompanying reduction in air pollutants, which have negative effects on human health, water quality and crop yields. Recent studies have found that climate change and air quality are closely interrelated with respect to the sources, atmospheric processes and environmental effects, reflecting the fact that fossil fuel combustion is a major source of both air pollution and GHG. One study found that cutting $\mathrm{CO}_{2}$ emissions by $10 \%$ to $20 \%$ compared to the business as usual baseline would reduce sulphur dioxides $\left(\mathrm{SO}_{2}\right)$ by the same amount and nitrogen oxides (NOx) by $5 \%$ to $10 \%$ over the next 10 to 20 years. ${ }^{20}$ The link between cuts in emissions in air pollutants - sulphur oxides, nitrogen oxides and carbon monoxide (CO) and volatile organic compounds (VOC) - and the decline in $\mathrm{CO}_{2}$ emissions by industry is evident in Japan. Indeed, emissions of air pollutants fell by a combined 24.6\% between 1990 and 2007 (Table 4). Given the strong link between air pollutants and $\mathrm{CO}_{2}$ emissions, the success in reducing emissions by the industrial sector and limiting those by the transport sector improved air quality. ${ }^{21}$ In addition, the decline in other GHG emissions may have contributed to the decline in air pollutants. The benefit, in terms of premature deaths avoided due to reduced air pollution, is estimated to be up to $\$ 50$ per tonne of $\mathrm{CO}_{2}$ equivalent removed (Burniaux et al., 2008).

20. The study is from the 4th assessment by the IPCC. Sulphur dioxides $\left(\mathrm{SO}_{2}\right)$ harm human health, contribute to acid deposition and may also harm crops and forests. Nitrogen oxides (NOx) emissions, which mainly stem from the burning of fossil fuels at high temperatures, play an important role in the production of photochemical oxidants and of smog, and contribute, together with SOx, to acid precipitation. Carbon monoxide $(\mathrm{CO})$ can cause adverse health effects, in particular because it interferes with the absorption of oxygen by red blood cells. Volatile organic compounds (VOC) are considered, along with NOx, to be the main precursors of photochemical air pollution (OECD Environmental Data, 2007).

21. Part of the reductions in $\mathrm{CO}_{2}$ emissions and air pollutants by industry may be due to rising foreign direct investment abroad by Japanese firms. While industrial production rose by $12 \%$ between 1990 and 2006, industries that tend to be more polluting may have increased overseas production. 
Figure 6. $\mathrm{CO}_{2}$ emissions from energy use by sector in Japan

A. $\mathrm{CO}_{2}$ emissions trend between 1990-2007 $\mathrm{Mn}$ tonnes of $\mathrm{CO}_{2}$

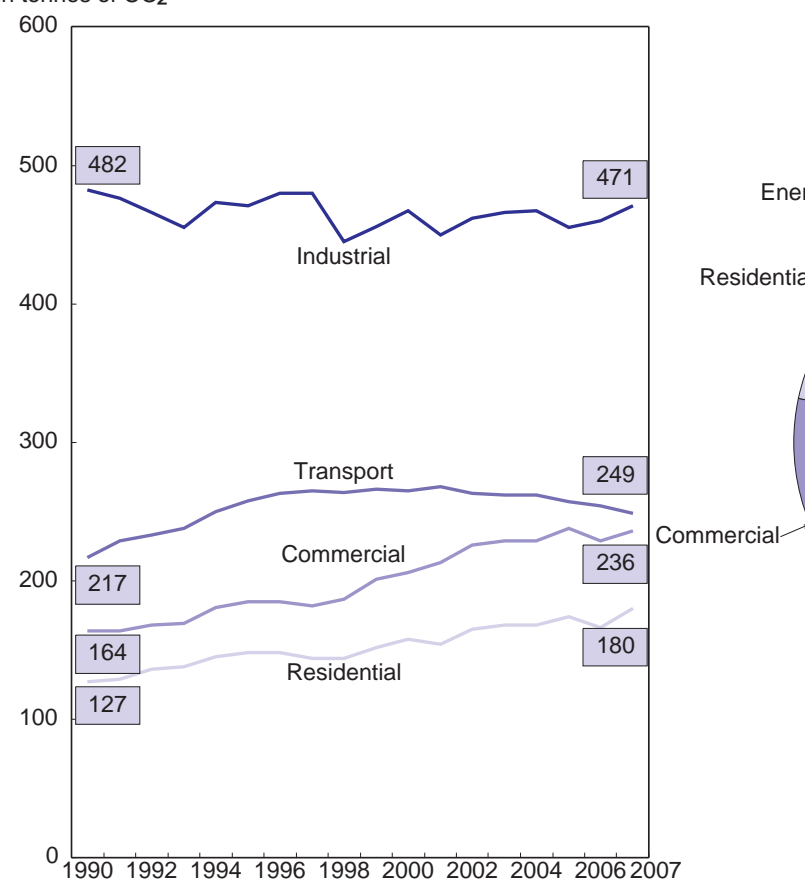

B. Composition of $\mathrm{CO}_{2}$ emissions in 2007

nergy conversion

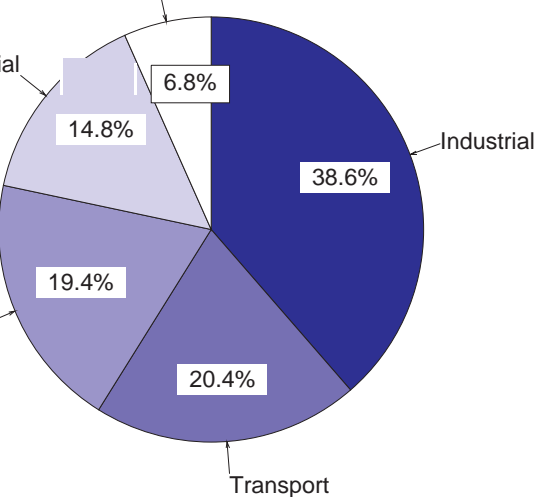

Source: Institute for Environmental Studies and GHG Inventory Office of Japan.

\section{Looking ahead to the post-Kyoto framework}

The 2007 Bali Action Plan launched the development of a new global framework beyond 2012. The G8 countries agreed at the 2008 Hokkaido Summit to "seek to share with all the Parties to the UNFCCC the vision" of at least a 50\% reduction in global emissions by 2050 (without specifying the basis for comparison). The Summit emphasised a successful partnership between developed and developing countries, the importance and urgency of stimulating the development and deployment of innovative technologies and practices and cost-effective measures to curb emissions. It also stated that sectoral approaches can be useful tools to improve energy efficiency and reduce GHG emissions. In international discussions in preparation for the COP 15 meeting in December 2009 in Copenhagen, Japan has focused on creating a fair and effective framework that includes all major economies.

Table 4. Changes in air pollutants and GHG emissions between 1990 and 2006

\begin{tabular}{c|ccc|c|ccc}
\hline \multicolumn{3}{c|}{ Air pollutants (1 000 tonnes) } & \multicolumn{3}{c}{ Other GHG emissions (Mt CO $_{2}$ eq.) } \\
\hline & 1990 & 2006 & $\begin{array}{c}\text { \% change } \\
1990-06\end{array}$ & & 1990 & 2006 & $\begin{array}{c}\% \text { change } \\
1990-06\end{array}$ \\
\hline $\mathrm{SO}_{2}$ & 1012 & 780 & -22.9 & $\mathrm{CH}_{4}$ & 32.6 & 22.6 & -30.7 \\
$\mathrm{NOx}$ & 2038 & 1943 & -4.7 & $\mathrm{~N}_{2} \mathrm{O}$ & 32.0 & 23.8 & -25.6 \\
$\mathrm{CO}$ & 4459 & 2761 & -38.1 & $\mathrm{HFCs}$ & 20.3 & 13.2 & -34.8 \\
VOC & 1937 & 1638 & -15.4 & PFCs & 14.4 & 6.5 & -54.9 \\
& & & & SF & 17.0 & 4.4 & -74.1 \\
\hline Total & 9446 & 7123 & -24.6 & Total & 117.1 & 70.5 & -39.4 \\
\hline
\end{tabular}

Source: Ministry of the Environment, 2008. 
In order to achieve its ambitious goals, Japan must improve its policy framework. First, the priority is to rely on market instruments to achieve emission reductions in a cost-effective manner rather than on the voluntary measures used thus far. Market-based instruments offer several advantages by setting a clear price. In the short run, market instruments minimise the cost of GHG reductions by equalising marginal abatement cost across all individual emitters. Over the long run, price-based systems provide incentives for firms to develop new technologies that lower reduction costs. Investors need a clear and credible price signal as early as possible to make appropriate investment decisions for the future. New technologies, such as carbon capture and storage, will not be deployed without a clear price for carbon. A market-based approach is clearly superior to a sector-specific approach that calculates energy efficiency by sector and adds up the reduction volume that can be achieved based on the technology to be used in the future. Second, Japan should make more use of the Kyoto mechanisms as the marginal cost of reducing emissions in Japan is relatively high due to its low carbon intensity. Linking its ETS to those in other countries and enlarging the CDM are the key options in this regard. Third, non-price instruments should also be strengthened to address market imperfections, to promote innovation for technological breakthroughs and support renewable energy.

\section{Making more use of market-based instruments}

\section{Emissions trading systems (ETS)}

A mandatory ETS based on cap and trade allows holders of permits the right to emit a certain amount of GHG, with the total amount of permits set at the overall desired future emissions by the covered sources. Emitters are allowed to buy and sell permits in an open market. One key question is how to allocate the permits. Japan's trial ETS grants permits for free, based on the targets of firms' voluntary action plans. Such a grandfathering approach is politically attractive and is often used to gain the support of incumbents. However, if emitters expect that such an approach will continue in the future, the incentives to reduce emissions would be weakened. Moreover, giving away permits to existing firms could act as an entry barrier, as new firms would face higher costs than existing firms, and it may encourage non-viable firms to stay in business to receive free emission permits. An alternative approach is to sell permits through an auction scheme, similar to the approach adopted for allocating frequency spectrum for mobile telephony. Although this approach is more costly for firms, it would provide revenues to help achieve fiscal consolidation and reduce the need for higher taxes and their associated distortions. In sum, auctioning permits is expected to enhance efficiency as compared with grandfathering. At the very least, policy makers should announce that grandfathering will be gradually phased out to create incentives to reduce emissions.

One option to cope with risk and uncertainty about prices in an ETS is to allow permits that are not used in the trading period in which they are issued to be saved or banked for the future. Such an approach increases efficiency by allowing firms to adjust their emissions reduction schedule to their investment programme. Recent analysis suggests that banking reduces abatement costs, while increasing the amount of GHG emission reductions even in the short term (Bosetti et al., 2008). The borrowing of permits has a similar effect, although there is a need for caution as firms do go bankrupt. Banking and borrowing, however, require adequate compliance mechanisms and long-term targets to be effective. Allowing firms to smooth their emissions profiles through the business cycle by banking and borrowing permits also helps to limit price volatility (Philibert and Reinaud, 2004). ${ }^{22}$

22. In the EU's ETS, for example, the spot price fell from over $€ 30$ per tonne of $\mathrm{CO}_{2}$ to under $€ 1$ between the spring of 2006 and the spring of 2007 in the absence of banking provisions, which were avoided in the pilot stage as they would have caused serious environmental damage. 
Another option is to set a floor and ceiling for the price in order to reduce the risk of large price fluctuations. However, such an approach would mask market signals and would prevent linking Japan's ETS to those in other countries. Another option to manage risk would be to set targets based on intensity (e.g. emissions per unit of output), rather than on the absolute amount of emissions, thereby allowing the automatic adjustment of emission objectives to unexpected shocks to economic growth and to marginal abatement costs (Ellis and Tirpak, 2006). However, intensity targets would also complicate international links with ETSs based on absolute amounts. In addition, the benefit of an intensity target would be smaller in a country such as Japan, where some estimate the potential growth rate at less than $1 \%$.

Given the ability of a well-designed ETS to efficiently reduce GHG emissions, Japan should shift from its voluntary system to a mandatory ETS based on cap and trade, ideally with the initial permits allocated by auctioning, drawing lessons from the experience of other countries and Japan's voluntary system. ${ }^{23}$ The scheme should include banking and possibly borrowing provisions to limit risk, uncertainty and volatility. The ETS should ideally cover the entire economy, including transport.

\section{Carbon taxation}

A carbon tax can also force emitters to equalise marginal abatement costs to the level of the tax, thereby ensuring that the least-expensive abatement options are exhausted. Although a carbon tax cannot set a fixed emission cap for the whole country (an advantage of an ETS), it can provide a clear price signal that promotes investment by the private sector in R\&D in energy-saving technology. A carbon tax also reduces the current demand for energy and makes the price of renewable energy sources more competitive. The government is discussing the possible introduction of a carbon tax. According to the National Institute for Environmental Studies in Japan, the introduction of a carbon tax of 2400 yen (\$26) per tonne in 2009 would reduce $\mathrm{CO}_{2}$ emissions by approximately $5 \%$ by $2020 .^{24}$

\section{The choice between an emissions trading scheme and a carbon tax}

Both a cap-and-trade ETS system and a carbon tax meet the efficiency criteria. Moreover, assuming that permits are auctioned, both give strong incentives for monitoring and enforcement by the authorities and generate revenues that can reduce taxes on labour, thereby increasing efficiency. A carbon tax has some advantages, as it is easy to adopt from a technical standpoint, has lower transaction costs and guarantees the maximum and minimum cost, although optimal carbon tax rates can change over time. Nevertheless, an ETS system is preferable for a number of reasons. First, an ETS creates the possibility of international linkages to cut emissions, which is very important in the case of Japan. Second, the participation of firms in the market for permits creates a strong constituency for maintaining the system. ${ }^{25}$ Third, an ETS can secure a more targeted level of emissions reduction than a carbon tax. Indeed, it is less certain in advance how much emissions will fall with a certain level of tax, and thus may require more iteration to achieve the desired level of emissions. Fourth, unlike a carbon tax, a trading scheme does not need to be adjusted for inflation or growth. However, even a fairly comprehensive ETS may exclude specific sectors, notably households and offices, leaving scope for a carbon tax to co-exist with an ETS. It is important, though, to minimise overlap and complicated interactions with an ETS that would raise uncertainty about the overall impact (OECD, 2006).

23. A mandatory cap and trade system is scheduled to be introduced in Tokyo from FY 2010, covering around $40 \%$ of total emissions from the commercial and industrial sectors in Tokyo.

24. Total revenue from such a carbon tax is estimated at around 360 billion yen ( $0.1 \%$ of GDP) per year. The tax burden on an average household would be 2000 yen (\$21) a year, according to a government estimate.

25. An ETS that gives away permits for free is less costly for firms than a carbon tax. As noted above, however, such an approach is less efficient than auctioning permits. 
As in other countries, a key obstacle to the implementation of an ETS and/or a carbon tax is concern about their impact on the international competitiveness of domestic industries. ${ }^{26}$ An effective climate policy requires that some firms do not survive, either because demand for their products falls or because more GHG-efficient firms, either domestic or foreign, increase their market share. However, OECD analysis has found that the effects of climate policies on competitiveness are likely to be small and limited to only a few energy-intensive industries, particularly if an ETS has broad international coverage (OECD, 2009a). Indeed, it is important to achieve wide coverage in the post-Kyoto framework. Otherwise, the emission cuts in some countries with an ETS and/or carbon tax are partly offset by increases elsewhere, a phenomenon referred to as carbon leakage. However, recent OECD research found that "Unless only a very few countries take action against climate change, leakage rates are found to be small, and they rapidly decrease as the group of participating countries taking action increases" (OECD, 2009b).

The negative political repercussions of firm bankruptcies could be addressed through allocation rules for permits in the case of an ETS. For a carbon tax, two remedies are possible (OECD, 2008d and Duval, 2008). First, the increase in revenues from a carbon tax could be offset by reductions in other business taxes, either at the sectoral level or for the corporate sector more generally. Second, the impact of a carbon tax on international competitiveness could be neutralised through sectoral exemptions and tax reductions that target the most exposed sectors. Indeed, the Japanese government is discussing relief measures for specific industries, such as exempting coal for manufacturing steel, to lessen the negative impact of a carbon tax. Moreover, the tax rate on large emitting businesses would be reduced by $80 \%$ on the condition that they achieve certain levels of reduction in $\mathrm{CO}_{2}$ emissions. The drawback of sectoral exemptions is that they would create uneven abatement incentives across sectors and a loss of efficiency. To increase efficiency, such exemptions, therefore, should be transitional and partial in terms of grandfathering.

\section{Reducing abatement costs by expanding the CDM and linking the ETS with other countries}

Japan would benefit more than any other country by expanding its use of the Kyoto Protocol mechanisms (Burniaux et al., 2009). If Japan relied exclusively on domestic emission reductions to achieve a $50 \%$ cut by 2020 (relative to 1990), Japan would have to set the highest carbon price in the world (Figure 7). In other words, Japan would have the highest marginal cost of abatement. Expanding the purchase of emission credits from other countries to account for $20 \%$ of the overall emission cuts would reduce the cost by more than half.

One method to increase purchases of emission credits, and thereby lower the marginal abatement cost in Japan, would be to expand its purchase of CDM credits from projects with developing countries, which have a vast low-cost abatement potential. However, scaling up the CDM in the short run is difficult given that its project-by-project approach creates bottlenecks and high transaction costs. Moreover, a sharp expansion of the CDM might strengthen existing concerns about its environmental integrity. A multilateral reform of the CDM mechanism is essential to address these concerns. Bottlenecks could be reduced by bundling projects and by the "programmes of activities" approach, which allows credits for a range of projects that differ in nature, timing and geographical location (Hinostroza et al., 2007). ${ }^{27}$ Transaction costs could be further reduced by introducing broader "policy" or "sectoral" CDM projects (Baron and Ellis, 2006 and Aldy and Stavins, 2008). Maintaining the environmental integrity of the CDM requires strengthening the additionality principle: planned reductions would not have occurred without the additional incentive provided by emission reduction credits. In addition to helping Japan, enlarging the

26. Another concern is a potentially adverse impact on income distribution from a carbon tax, reflecting its regressive nature. While this problem can be addressed, at least in principle, via the tax-benefit system, this option is not always available in lower-income countries with weaker social policy settings (Duval, 2008).

27. The "programme of activities" approach has been eligible for CDM credits since 2005 (OECD, 2009b). 
scope of the CDM would put a price on carbon in developing countries and promote technology transfers to developing countries, thereby facilitating their participation in global efforts to cut emissions. Japan has developed a manual to help quantify the effectiveness of its CDM projects that achieve the dual objectives of reducing emissions and mitigating local environmental problems (so called co-benefits).

Figure 7. Carbon prices under a 50\% emission cut by 2020

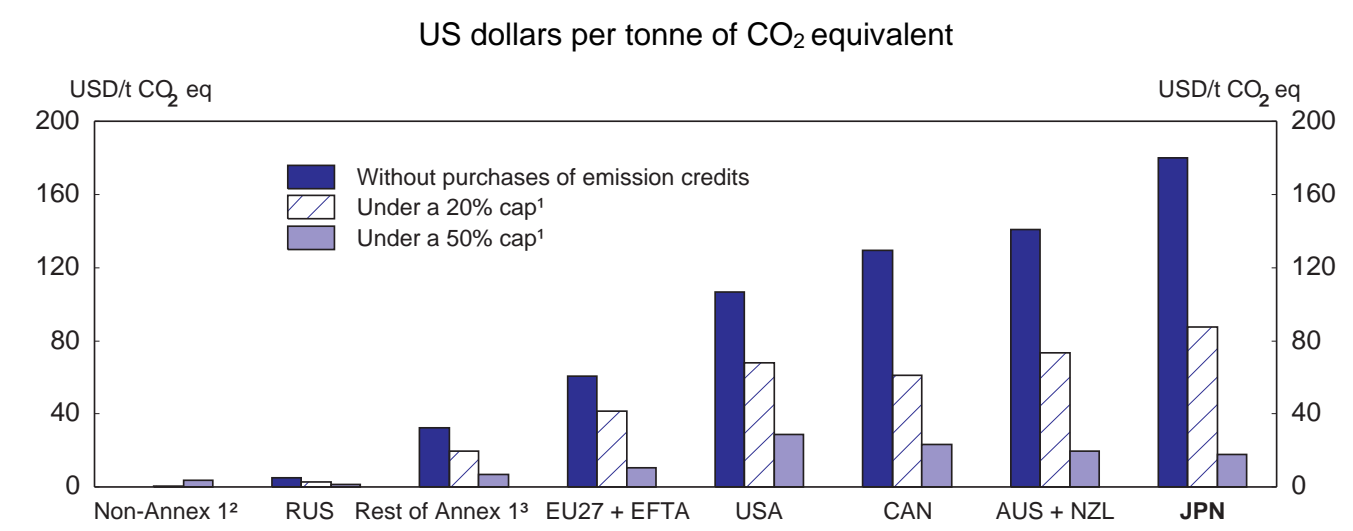

1. Assumes that purchases of emissions credits account for $20 \%$ or $50 \%$ of the country/region's required emission reductions. This simulation is based on a perfect crediting mechanism without the bottlenecks and additionality problems under the current CDM.

2. Annex 1 includes industrialised countries belonging to the OECD in 1992, plus economies in transition (such as those in Central and Eastern Europe, Russia and the Baltic States). Non-Annex 1 is thus primarily developing countries.

3. Annex 1 countries that are not shown individually in the figure.

Source: Burniaux et al., OECD (2009).

A second option to increase purchases of emission credits from other countries would be to link any future ETS in Japan to those in other countries, thereby allowing domestic emission reductions to be met by buying allowances in an international permit market. The wider the coverage of the ETS in terms of regions and industries, the greater the trading options and the cost efficiency. Moreover, linking national schemes would mitigate the impact of country-specific shocks and thereby reduce the amplitude of price fluctuations. Several ETSs are already, or soon will be, in place, ${ }^{28}$ but none of them are directly linked. The European Union has a plan to create an OECD-wide carbon market by 2015 and extend it to advanced developing countries by 2020 (EC, 2009). In practice, however, creating an international market by linking national ETSs is complicated by large cross-country differences in their systems (Capoor and Ambrosi, 2006 and Ellis and Tirpak, 2006). ${ }^{29}$ Governments should facilitate international linkages by harmonising the structure of their ETS, including the procedure for setting future emission caps, the choice of target (absolute or relative to GDP), the allocation rule for permits ${ }^{30}$ and future adjustment procedures.

28. ETSs are already in place or are about to be implemented in the European Union, Australia, Canada, New Zealand, Norway and some states in the north-eastern part of the United States. A growing number of other countries are considering introducing an ETS (Burniaux et al., 2008).

29. Linking to other schemes may raise a number of other concerns: i) expectations of linking might induce national policy makers to engage in strategic behavior, e.g. by setting a less stringent emission cap; ii) design features that make the emission cap more flexible in one particular country would de facto become available to emitters in all other countries once schemes are linked; and iii) linking raises a communication challenge in those areas where local emission targets exist, as it implies a loss of sovereignty over both the quantity and the price of emissions (Duval, 2008).

30. Harmonising the allocation rules would encourage international integration by ensuring a level playing field across countries. Auctioned permits make firms' costs higher, weakening their competitiveness relative to firms in other countries where a grandfathering rule is applied. 


\section{Using non-price instruments to address market imperfections}

Although price-based instruments are essential to achieve emission cuts at the lowest cost possible and to provide incentives for the development and diffusion of greener technologies, they need to be accompanied by other policy instruments to address market imperfections. Some markets are less responsive to price signals, particularly when a small number of large firms are dominant or there are information asymmetries. For example, in the rental housing market, landlords have better information than tenants concerning insulation of buildings but have little incentive to install the most energy-efficient equipment as they do not pay the energy bill. In addition, there are areas where measurement and enforcement are difficult, reducing the effectiveness of price-based instruments. For instance, strict technical requirements may be needed to prevent leakage from gas pipelines. Therefore, command-andcontrol (CAC) regulatory instruments, which have traditionally been used to achieve environmental goals, still have a role to play in coping with market imperfections that cannot be adequately addressed by pricebased mechanisms. Such regulation can be divided into technology standards, which force emitters to use specific abatement technologies, and performance standards, which set certain targets to be met without designating specific technologies. In the absence of detailed information about abatement costs, there is a risk that technology standards will be either too stringent or too lax. Moreover, technology standards, unlike those on performance, do not allow firms and consumers to choose among alternative abatement options. For Japan, it would be useful to strengthen performance standards on energy use in commercial and residential buildings in light of the rapid increase in their emissions.

In general, though, Japan needs to put more emphasis on price-based instruments rather than the traditional CAC approach, which does not lead to cost-effective solutions. As market approaches prove to be effective, CAC instruments, such as the Top Runner Programme, should be phased out, as having several policies to achieve the same target creates uncertainty for firms and is unlikely to be cost-effective.

Price signals alone do not ensure adequate $R \& D$ and innovation. This market failure is common to all types of $R \& D$, but is magnified in the area of climate change by policy uncertainty and weak protection of intellectual property rights (IPR). ${ }^{31}$ Specific policies, in addition to price-based instruments, are needed therefore to foster R\&D and the development of renewable energy sources. In particular, the government should invest directly in basic R\&D to share the risk of developing new technologies with the private sector in order to achieve the innovations necessary to meet the targeted reductions in emissions.

Japan's public R\&D expenditure in energy-related areas was the second largest in the world in 2007 in absolute amounts after the United States and the largest as a share of GDP. The high level of investment has helped make Japan one of the leading countries in climate-related technological innovation, accounting for around 40\% of world inventions in this area between 1998 and 2003 (Table 5). The development of new technology is essential, given that existing technology is not sufficient to achieve the ambitious emission reduction targets of $60 \%$ to $80 \%$ by 2050 . Japan has announced a long-term strategy and roadmap for innovation, including the 2008 Cool Earth Promotion Programme that targets $\$ 30$ billion $(0.6 \%$ of 2008 GDP) in public funding for R\&D investment in this area over the next five years. The government expects that the accelerated development of climate-related technologies will contribute not only to large reductions in emissions but also to Japan's international competitiveness.

31. Weak protection of IPR is likely to be particularly problematic in R\&D related to climate change for two reasons. First, developing countries may consider access to the most efficient abatement technologies to be an important condition for their participation in emission abatement efforts. This weakens the credibility of IPR and thus reduces firms' incentive to innovate. Second, the value of R\&D in climate change depends on the credibility of governments' abatement policies. If firms are uncertain that governments will follow through on their intended policies, their incentives to invest in such R\&D are weakened (OECD 2008b). 
ECO/WKP(2009)81

Table 5. Top ten nations in inventing climate-related technologies, 1998-2003

\begin{tabular}{lcl}
\hline \multicolumn{1}{c}{ Country } & $\begin{array}{c}\text { Share of world } \\
\text { inventions (\%) }\end{array}$ & \multicolumn{1}{c}{ Most important technology classes } \\
\hline Japan & 40.8 & All technologies \\
United States & 12.8 & Wind, solar, hydro, methane, buildings \\
Germany & 12.7 & Biomass, ocean, waste, CCS, ${ }^{1}$ wind, solar \\
China & 5.8 & Cement, geothermal, solar, hydro, methane \\
Korea & 4.6 & Lighting, ocean, hydro, biomass, cement \\
Russia & 4.2 & Geothermal, cement, hydro, CCS, ${ }^{1}$ ocean \\
France & 2.4 & Cement, CCS, ${ }^{1}$ buildings, biomass, hydro \\
United Kingdom & 1.9 & Ocean, biomass, wind, methane \\
Canada & 1.5 & Hydro, wind, CCS, ${ }^{1}$ ocean \\
Brazil & 1.1 & Ocean, building \\
\hline
\end{tabular}

1. Carbon capture and storage.

Source: Dechezleprêtre et al., 2008.

\section{Conclusion}

Climate-change policy should minimise the overall economic cost of achieving emissions reduction targets by equalising marginal abatement costs across all emission sources. However, the wide range of policies in place will lead to large variations in marginal abatement costs. The priority is to establish instruments that achieve cost-effectiveness by putting a clear price on carbon, while fostering innovation and the diffusion of technologies in an uncertain environment. Specific policy recommendations to improve Japan's climate-change policy are provided in Box 2.

\section{Box 2. Summary of recommendations to improve policies on climate change}

- $\quad$ Continue efforts to achieve a comprehensive, fair and effective international agreement for the post-Kyoto framework that includes all developed and major developing countries.

\section{Price-based instruments}

- $\quad$ Shift policies from voluntary measures to market-based instruments to achieve GHG emission reduction targets in a cost-effective way by ensuring that abatement costs are equal at the margin across all options.

- $\quad$ Put a price on carbon emissions by introducing a mandatory and comprehensive cap-and-trade ETS as the first priority, drawing lessons from the experience of other countries and Japan's voluntary system, to provide a clear price signal that enables market participants to make appropriate investment decisions.

- Implement a carbon tax in areas not covered by the ETS and use the revenue, together with that from auctioning permits for the ETS, to improve the fiscal consolidation.

- Use auctions to allocate the ETS permits, which can be banked for the future and borrowed, and link Japan's ETS with those in other countries to achieve cost-effective abatement.

- $\quad$ Expand the number and amount of projects in a streamlined and upscaled CDM with a high level of environmental integrity to utilise the vast low-cost abatement potential in developing countries through technology transfer, while avoiding the diversion of ODA funds.

\section{Non-price instruments}

- Rely on performance-based regulation and, when necessary, technology-based standards, in areas where 
ECO/WKP(2009)81

price instruments are ineffective.

- Improve energy efficiency policies, such as the Top Runner Programme, in the short run, while phasing them out as market-based instruments become effective.

- Continue to promote the innovation and diffusion of energy-saving and abatement technologies by supplementing private-sector R\&D with public investment focused on infrastructure and basic research and by sharing the risk of creating new technologies with the private sector, particularly in large-scale projects.

- Use transparent and efficient instruments to support the development of renewable energy in the short run, while relying on the pricing of GHG emissions in the long run. 
ECO/WKP(2009)81

\section{BIBLIOGRAPHY}

Aldy, E. and R. Stavins (2008), "Economic Incentives in a New Climate Agreement", Issue Paper, The Harvard Project on International Climate Agreements, Cambridge, MA.

Baron, R. and J. Ellis (2006), Sectoral Crediting Mechanisms for Greenhouse Gas Mitigation: Institutional and Operational Issues, OECD/IEA, Paris.

Bosetti, V., C. Carraro and E. Massetti (2008), "Banking Permits: Economic Efficiency and Distributional Effects", CESifo Working Paper Series No. 2214.

Burniaux, J.-M., J. Chateau, R. Duval and S. Jamet (2008), "The Economics of Climate Change Mitigation: Policies and Options for the Future", OECD Economics Department Working Papers No. 658, OECD, Paris.

Burniaux, J.-M., J. Chateau, R. Dellink, R. Duval and S. Jamet (2009), "The Economics of Climate Change Mitigation: How to Build the Necessary Global Action in a Cost-Effective Manner", OECD Economics Department Working Papers No. 701, OECD, Paris.

Capoor, K. and P. Ambrosi (2006), State and Trends of the Carbon Market 2006, IETA and World Bank.

Dechezleprêtre, A., M. Glachant, I. Hascic, N. Johnstone and Y. Ménière (2008), "Invention and Transfer of Climate Change Mitigation Technologies on a Global Scale: A Study Drawing on Patent Data", mimeo, Agence Française de Développement.

Duval, R. (2008), "A Taxonomy of Instruments to Reduce Greenhouse Gas Emissions and their Interactions”, OECD Economics Department Working Papers No. 636, OECD, Paris.

Ellis, J. and D. Tirpak (2006), Linking GHG Emission Trading Systems and Markets, OECD/IEA, Paris.

Energy Conservation Centre, Japan (2008), Top Runner Programme, January, Tokyo.

European Commission (2009), Towards a Comprehensive Climate Change Agreement in Copenhagen, $\operatorname{COM}(2009) 39$ final, January, Brussels.

Goodstein, E. (2007), Economics and the Environment, John Wiley \& Sons, Chichester, U.K.

Government of Japan (2008), Action Plan for Achieving a Low Carbon Society, Tokyo.

Hinostroza, M., C.-C. Cheng, X. Zhu, J. Fenhann, C. Figueres and F. Avendano (2007), "Potential and Barriers for End-Use Energy Efficiency Under Programmatic CDM", CD4CDM Working Papers No. 3, UNEP RISO Centre.

Houghton, J. (2004), Global Warming: The Complete Briefing, Cambridge University Press, Cambridge. 
ECO/WKP(2009)81

IPCC (2007), Fourth Assessment Report, Climate Change 2007, Paris.

Ito, K. (2007), "Setting Goals and Action Plan for Energy Efficiency Improvement, Energy Efficiency and Conservation", Presentation at the EAS Energy Efficiency and Conservation Conference, 18 June.

Lankoski, L. (2009), "Linkages between Environmental Policy and Competitiveness", Environment Directorate Working Paper, forthcoming, OECD, Paris.

Ministry of the Environment (2008), National Greenhouse Gas Inventory Report of Japan, Tokyo.

Ministry of Economy, Trade and Investment (2008), Cool Earth - Innovative Energy Technology Program, Tokyo.

Ministry of Foreign Affairs (2009), Japan's ODA White Paper 2008, Tokyo.

NEDO (2008), Outline of NEDO 2008-2009, New Energy and Industrial Technology Development Organization, Tokyo.

Nippon Keidanren (2007), Results of the FY 2007 Follow-up to the Keidanren Voluntary Action Plan on the Environment, Tokyo.

Nordqvist, J. (2006), Evaluation of Japan's Top Runner Programme, The Active Implementation of the Proposed Directive on Energy Efficiency (AID-EE).

OECD (2002), Environmental Performance Reviews: Japan, OECD, Paris.

OECD (2003), Voluntary Approaches for Environmental Policy: Effectiveness, Efficiency, and Usage in the Policy Mix, OECD, Paris.

OECD (2006), The Political Economy of Environmentally Related Taxes, OECD, Paris.

OECD (2007), Environmental Data, Compendium 2006/2007, OECD, Paris.

OECD (2008a), Biofuel Support Policies: An Economic Assessment, OECD, Paris.

OECD (2008b), Climate Change Mitigation, What Do We Do?, OECD, Paris.

OECD (2008c), Energy Policies of IEA Countries, Japan 2008 Review, IEA/OECD, Paris.

OECD (2008d), Environmentally Related Taxes and Tradable Permit Systems in Practice, OECD, Paris.

OECD (2008e), Renewables Information, OECD, Paris.

OECD (2009a), First Interim Report on the OECD's Strategic Response to the Financial and Economic Crisis, OECD, Paris.

OECD (2009b), "Progress Report Ch Climate (http://www.olis.oecd.org/olis/2009doc.nsf/LinkTo/NT00004876/\$FILE/JT03266177.PDF), OECD, Paris.

Ogawa, J. (2008), Revised Kyoto Protocol Target Achievement Plan - Overview and History of Revision, Institute of Energy Economics Japan, Tokyo. 
Overseas Environmental Cooperation Center (2008), Co-benefits Approach to Climate Change and CDM in Developing Countries, Tokyo.

Philibert, C. and J. Reinaud (2004), "Emissions Trading: Taking Stock and Looking Forward", http://www.oecd.org/dataoecd/58/59/32140134.pdf, OECD/IEA, Paris.

Roberts, M. and M. Spence (1976), "Effluent Charges and Licenses under Uncertainty", Journal of Public Economics, Vol. 5, No. 3-4.

Stern, N. (2007), The Economics of Climate Change: The Stern Review, Cambridge University Press, Cambridge, U.K. 
ECO/WKP(2009)81

\section{WORKING PAPERS}

The full series of Economics Department Working Papers can be consulted at www.oecd.org/eco/working_papers/

739. Health-care reform in Japan: controlling costs, improving quality and ensuring equity (December 2009) by Randall S. Jones

738. Financial stability: overcoming the crisis and improving the efficiency of the banking sector in Japan

(December 2009) by Randall S. Jones and Masahiko Tsutsumi

737. Recent Oil Price Movements- Forces and Policy Issues

(December 2009) by Eckhard Wurzel, Luke Willard and Patrice Ollivaud

736. Promoting competition to strengthen economic growth in Belgium

(December 2009) by Tomasz Koźluk

735. Prudential Regulation And Competition In Financial Markets

(November 2009) by Rüdiger Ahrend, Jens Arnold and Fabrice Murtin

734. Keeping slovénian public finances on a sustainable path

(October 2009) Pierre Beynet and Willi Leibfritz

733. Pedal to the metal: Structural reforms to boost long-term growth in Mexico and spur recovery from the crisis

(October 2009) David Haugh and Agustin Redonda

732. Achieving higher performance: Enhancing spending efficiency in health and education in Mexico (October 2009) Cyrille Schwellnus

731. Russia's long and winding road to a more efficient and resilient banking sector (October 2009) Geoff Barnard

730. How do institutions affect structural unemployment in times of crises?

(October 2009) Davide Furceri and Annabelle Mourougane

729. Understanding the world trade collapse

(October 2009) Calista Cheung and Stéphanie Guichard

728. Estonia and euro adoption: Small country challenges of joining EMU

(October 2009) Zuzana Brixiova, Margaret H. Morgan and Andreas Wörgötter

727 Towards better schools and more equal opportunities for learning in Italy

(June 2009) Romina Boarini

726. Iceland: Challenging Times for Monetary and Fiscal Policies

(August 2009) Andrea De Michelis

725. Iceland: The Financial and Economic Crisis

(August 2009) David Carey 
724. The role of transparency in the conduct of monetary policy (September 2009) Makoto Minegishi and Boris Cournède

723. Raising education outcomes in Greece (September 2009) Vassiliki Koutsogeorgopoulou

722. Improving the performance of the public health care system in Greece (September 2009) Charalampos Economou and Claude Giorno

721. Is there a case for price-level targeting?

(August 2009) Boris Cournède and Diego Moccero

720. The challenge of restoring French competitiveness (August 2009) Rafal Kierzenkowski

719. Improving the functioning of the Slovenian labour market (August 2009) Isabell Koske

718. What drives sovereign risk premiums? An analysis of recent evidence from the Euro Area (July 2009) David Haugh, Patrice Ollivaud, and David Turner

717. The English National Health Service: an economic health check (July 2009) Peter Smith and Maria Goddard

716. Financial stability in the United Kingdom: Banking on prudence (July 2009) Philip Davis

715. Economic growth and the role of taxation- disaggregate data (July 2009) Gareth D. Myles

714. Economic growth and the role of taxation - Aggregate data (July 2009) Gareth D. Myles

713. Economic growth and the role of taxation - Theory (July 2009) Gareth D. Myles

712. The effectiveness of education and health spending among Brazilian municipalities (July 2009) Luiz de Mello and Mauro Pisu

711. The bank lending channel of monetary transmission in Brazil: A VECM approach (July 2009) Luiz de Mello and Mauro Pisu

710. How does decentralised minimum-wage setting affect unemployment and informality? The case of Indonesia (July 2009) Margherita Comola and Luiz de Mello

709. Intergenerational social mobility in European OECD countries (July 2009) Orsetta Causa, Sophie Dantan and Åsa Johansson

708. Equity in student achievement across OECD countries: an investigation of the role of policies (July 2009) Orsetta Causa and Catherine Chapuis 